\title{
Quaternary uplift rates of the Central Anatolian Plateau, Turkey: Insights from cosmogenic isochron-burial nuclide dating of the Kızılırmak River terraces
}

\author{
Attila Çiner ${ }^{1}$, Uğur Doğan ${ }^{2}$, Cengiz Yıldırım ${ }^{1}$, Naki Akçar ${ }^{3}$, Susan Ivy-Ochs ${ }^{4}$, Vasily \\ Alfimov $^{4}$, Peter W. Kubik ${ }^{4}$, Christian Schlüchter ${ }^{3}$
}

(1) Eurasia Institute of Earth Sciences, Istanbul Technical University, Maslak, 34469 Istanbul, Turkey

(2) Department of Geography, Ankara University, 06100 Sihhıye, Ankara, Turkey

(3) University of Bern, Institute of Geological Sciences, Baltzerstrasse 1-3, 3012 Bern,
Switzerland

(4) Institute of Particle Physics, ETH Hönggerberg, 8093 Zurich, Switzerland

\begin{abstract}
The Central Anatolian Plateau (CAP) in Turkey is a relatively small plateau (300 x $400 \mathrm{~km}$ ) with moderate average elevations of $\sim 1 \mathrm{~km}$ situated between the Pontide and Tauride orogenic mountain belts. Kizılırmak, which is the longest river $(1355 \mathrm{~km})$ within the borders of Turkey, flows within the CAP and slowly incises into lacustrine and volcaniclastic units before finally reaching the Black Sea. We dated the Cappadocia section of the Kizilirmak terraces in the CAP by using cosmogenic burial and isochron-burial dating methods with ${ }^{10} \mathrm{Be}$ and ${ }^{26} \mathrm{Al}$ as their absolute dating can provide insight into long-term incision rates, uplift and climatic changes. Terraces at 13, 20, 75 and $100 \mathrm{~m}$ above the current river indicate an average incision rate of $0.051 \pm 0.01 \mathrm{~mm} / \mathrm{yr}(51 \pm 1 \mathrm{~m} / \mathrm{Ma})$ since $\sim 1.9 \mathrm{Ma}$. Using the base of a basalt fill above the modern course of the Kizilirmak, we also calculated 0.05-0.06 mm/yr mean incision and hence rock uplift rate for the last $2 \mathrm{Ma}$. Although this rate might be underestimated due to normal faulting along the valley sides, it perfectly matches our results obtained from the Kizılırmak terraces. Although up to 5 to 10 times slower, the Quaternary uplift of the CAP is closely related to the uplift of the northern and southern plateau margins respectively.
\end{abstract}

Keywords: Isochron-burial dating, burial dating, depth-profile dating, surface exposure dating, fluvial terrace, fluvial incision, denudation rate, K1z1lırmak River. 


\section{Introduction}

Orogenic plateaus around the world demonstrate several common characteristics, such as anomalous lithospheric thickness, magmatic activity, high heat flow, and complex interactions between tectonic and climatic processes and therefore are among the best geological settings to investigate the synergistic interaction between deep-seated and surface processes to shape Earth's topography (Kay and Kay, 1993; Molnar et al., 1993; Allmendinger et al., 1997; Clark and Royden, 2000; Garzione et al., 2006; Faccenna et al., 2010, 2014; Göğüş and Pysklywec, 2008; Çiner et al., 2013; Schildgen et al., 2013, 2014). In tectonic plateaus, uplift and associated fluvial incision combined with climatic changes has created strath and fill terraces that constitute valuable proxies for the recent uplift and climatic history of the plateaus (Demir et al., 2004; Doğan, 2011; Schildgen et al., 2012a; Y1ldırım et al., 2011, 2013a). The radiometric dating of the fluvial terraces and spatio-temporal variations of uplift rates can provide patterns of deformations from crustal to individual fault scales (Lavé and Avouac, 2000, 2001; Hetzel et al., 2002; Maddy, 1997; Maddy et al., 2007; Wegman and Pazzaglia, 2009; Schildgen et al., 2012a; Y1ldırım et al., 2013a,b).

The Central Anatolian Plateau (CAP) in Turkey constitutes a relatively small orogenic plateau (300 x $400 \mathrm{~km}$ ) compared to Tibet or Altiplano (e.g., Wang et al., 2014) (Fig. 1). The CAP is located between the Central Pontide Mountains in the north, which border the Black Sea and Taurus Mountains in the south that abut the Mediterranean Sea, with elevations more than 3 $\mathrm{km}$ in places, creating significant barriers to modern precipitation (Mazzini et al., 2013; Schemmel et al., 2013). Despite its relatively modest mean elevation of $\sim 1 \mathrm{~km}$ and low overall exhumation, the CAP is an important geomorphic consequence of long-term lithospheric and climatic events in the Eastern Mediterranean (Çiner et al., 2013).

At both margins of the plateau, tectonic uplift and associated fluvial incision combined with climatic changes has created deeply incised gorges with strath and fill terraces that constitute valuable proxies for the recent uplift history (Demir et al., 2004; Schildgen et al., 2012a; Y1ldirım et al., 2011, 2013a,b). The southern margin furthermore contains up to $2 \mathrm{~km}$ uplifted marine sediments, providing a longer-term perspective on surface uplift since Late Miocene (Karabıyıkoğlu et al., 2000, 2005; Deynoux et al., 2005; Monod et al., 2006; Çiner et al., 2008, 2009; Cosentino et al., 2012a,b; Schildgen et al., 2012a,b, 2014; Cipollari et al., 2013a,b; Ilgar et al., 2013; Faranda et al., 2013).

While much attention has been focused on the timing and mechanisms of uplift concerning the southern and northern margins, our knowledge concerning the Quaternary uplift rates within the CAP are less known with few exceptions obtained from basalts covering fluvial terraces (Doğan, 2011) and relative offsets of faulted Pliocene lacustrine limestones intercalated with ignimbrite layers (Kürçer and Gökten, 2012; Aydar et al., 2013; Özsayın et al., 2013). Furthermore, Schildgen et al., (2013) concluded that as current mean elevations in the CAP are $\sim 1 \mathrm{~km}$ and the region was mainly terrestrial since at least Early Miocene (Akgün et al., 2007), the interior must have experienced less than $1 \mathrm{~km}$ surface uplift since the Late Miocene. Throughout the CAP and its margins, Late Miocene to present uplift rate estimates change from 0.02 to $0.74 \mathrm{~mm} / \mathrm{yr}$ (Cosentino et al., 2012a,b; Doğan, 2010, 2011; Schildgen et al., 2012a,b; Y1ldırım et al., 2013a,b). 
Our study area is located in the Cappadocia Volcanic Province (CVP) where several flights of fluvial terraces of the Kizılırmak are preserved. We applied isochron-burial (Balco and Rovey, 2008), burial, depth-profile and surface exposure dating methods with cosmogenic ${ }^{10} \mathrm{Be},{ }^{26} \mathrm{Al}$ and ${ }^{36} \mathrm{Cl}$ on the Kizılirmak terraces. The absolute dating of terraces can provide insight into long-term incision rates and climatic changes (Repka et al., 1997; Bridgland, 2000; Maddy et al., 2001; Antoine et al., 2003; Bridgland and Westaway, 2008 and references therein; Gibbard and Lewin, 2009). Additionally, in an attempt to constrain incision rates for the last $2 \mathrm{Ma}$ in the CAP, we also used a basaltic lava flow that filled a paleo-valley of a tributary of the Kizılirmak to constrain denudation rates.

In this study we present (1) abandonment ages of the terrace surfaces based on burial and isochron-burial dating with cosmogenic ${ }^{10} \mathrm{Be}$ and ${ }^{26} \mathrm{Al}$; (2) the long-term incision rate of the Kizilırmak as a proxy for the rock uplift; (3) the long-term denudation rate of this part of the CAP. Given these informations, we strived to reveal the interaction between climatic and lithospheric processes that might have impact on the topography of the CAP.

\section{Regional tectonic setting}

The CAP arises between one of the world's most seismically active tectonic structures, the Northern Anatolian Fault in the north and the Cyprus and Hellenic subduction zones to the south, the Aegean extensional zone to the west, and the Bitlis-Zagros collision zone to the east (Fig. 1). The Anatolian plate has been extruding toward the west with respect to Eurasia since Miocene as the result of extension in the Aegean (Gautier et al., 1999) and collision in the eastern Anatolian (Arabia-Eurasia collision) (McKenzie, 1972; Şengör and Y1lmaz, 1981). The CAP is formed of tectonic units assembled during Mesozoic to Tertiary orogenies (e.g., $\square$ engör and Y1lmaz, 1981; Robertson and Dixon, 1984; Pourteau et al., 2010). Related rocks are unconformably covered by extensive and thick successions of Late Miocene and Quaternary ignimbrites and lava flows of the CVP and are intercalated with fluvio-lacustrine deposits (Pasquaré, 1968; Innocenti et al., 1975; Temel et al., 1998; Toprak, 1998; Şen et al., 2003; Le Pennec et al., 2005; Aydar et al., 2012).

In the study area four Quaternary basalt lava flows, $\sim 2$ to $5 \mathrm{~m}$ thick in places, cover several levels of Kizılırmak terraces in the CAP (Doğan, 2011). The Kizılırmak is the longest river $(1355 \mathrm{~km})$ within the borders of Turkey. Its source area is situated to the east, and after drawing a large arc within semiarid CAP, the river flows to the north and reaches the Black Sea forming a major delta plain (Fig. 1a). In the study area the Kizllirmak flows through the volcanic rocks and lacustrine deposits of the CVP. The river flows within a depression controlled by the Salanda Fault to the north and the Tuzköy Fault to the south (Fig. 1b). The Kizilirmak drainage system is thought to be slightly younger than a regional key ignimbrite horizon (Valibaba Ignimbrite; Aydar et al., 2012), and a tentative age of 2.5-2.3 Ma was proposed by Doğan (2011). He also obtained ${ }^{40} \mathrm{Ar} /{ }^{39} \mathrm{Ar}$ weighted plateau ages of four basalt flows that cap four fluvial terraces, the highest one being $160 \mathrm{~m}$ above the current river level. Doğan (2011) proposed a minimum age between 2 Ma to $95 \mathrm{ka}$ for the underlying fluvial deposits. In the study area, throughout its evolution, the K1z1lırmak shifted towards south confining itself between the Yüksekli and Tuzköy Faults that show strike-slip characteristics with considerable amount of normal components (Doğan, 2010, 2011) (Fig. 2). We focused 
our study on an area between Yüksekli (Gülşehir section; Fig. 2a) and Sarıhıdır villages (Avanos section; Fig. 2b) where the river flows from 930 to $890 \mathrm{~m}$ and where several strath terraces can be traced within appreciable distances.

\section{Methods}

\subsection{Terrace straths elevations}

River strath terraces are often used to measure the rate of vertical stream incision, typically interpreted as the rate of base level fall, inclusive of rock uplift and associated crustal deformation (Bridgland, 2000; Wegmann and Pazzaglia, 2009; Rixhon et al., 2011). The sediments deposited above the bedrock with a basal unconformity called "strath" often vary in terms of facies and thickness. In situations where fluvial sediments are less than $3 \mathrm{~m}$ thick, they are considered to represent the mobile alluvial cover of bedrock channels (Pazzaglia and Brandon, 2001) and the landform is named a "strath terrace", (Bucher, 1932; Bull, 1991).

The reference frame for river incision uplift rate calculations is taken as the base level of the river, which is graded to sea level (Erlanger et al., 2012). In case the river gradient does not change substantially as sea level fluctuates, the long-term river incision rates are not very sensitive to sea-level changes over time (Merritts et al., 1994). This is the case for Kiz1lirmak that drains without significant changes along its river course across the flat lying CAP for several hundreds of kilometers. We therefore assumed net incision as net rock uplift in our calculations (e.g., Maddy et al., 2001; Westaway et al., 2004, 2006).

Fifteen river terraces that were previously described in detail by Doğan (2011) were used in this study as a base for field observations. For the sake of simplicity, we also adopted the terminology for terraces; $\mathrm{T} 1$ for the oldest terrace situated at $160 \mathrm{~m}$ above the actual river and T15 for the youngest. In this scheme, strath elevation of each terrace level is taken into account to represent the elevation from the actual river. However, we used the exact sampling elevations from where the cosmogenic ages and uplift rates were calculated relative to the actual river. A handheld GPS was used to measure coordinates of the samples and elevations of the terraces except for T6, T9 and T13 where we used a differential GPS.

\subsection{Cosmogenic nuclide dating}

We used cosmogenic ${ }^{10} \mathrm{Be},{ }^{26} \mathrm{Al}$ and ${ }^{36} \mathrm{Cl}$ to reconstruct the chronology of the Kiz1lirmak terraces. These nuclides are most often used for surface exposure dating, for instance, samples from a fluvial terrace (e.g., Repka et al., 1997) or glacial boulders (e.g., Sarıkaya et al., 2014) are analyzed and an age since deposition can be determined. Burial dating and isochron-burial dating (e.g., Balco et al., 2013) are fundamentally different from surface exposure dating and depth-profile dating (e.g., Hidy et al., 2010). The former depends on the decay of the nuclides, while the latter depends on the build-up. In addition, burial dating and isochron-burial dating require measurement of both ${ }^{10} \mathrm{Be}$ and ${ }^{26} \mathrm{Al}$.

Depth-profile dating uses the fact that cosmogenic nuclide production decreases predictably with depth, i.e. it follows known physical principles (Hancock et al., 1999). From the top of a deposit downward for about $2 \mathrm{~m}$, production of ${ }^{10} \mathrm{Be}$ drops off roughly exponentially with depth (Gosse and Phillips, 2001). The attenuation length and relative contribution to production due to spallation $(\sim 97 \%)$ and muons have been studied (Heisinger et al., 2002a,b; 
Balco et al., 2008; Braucher et al., 2011, 2013). Concentrations of ${ }^{10} \mathrm{Be}$ are measured in numerous samples of sand or $>50$ clasts amalgamated together (Ivy-Ochs et al., 2013 and references therein), and a curve is fit to the data. The shape of the curve is dependent on both the age of deposition of the sediment and the erosion (denudation) rate of the top surface. Recent work by Hidy et al., (2010) has improved the calculations, allowing Monte Carlobased simulations for determination of both age and top surface erosion rate. For depth-profile dating, several (6-10) samples are taken at intervals of tens of centimeters downwards into a deposit. Several recent studies have shown the viability and broad applicability of depthprofile dating (Matmon et al., 2006; Hidy et al., 2010; Haghipour et al., 2012 among others).

Burial dating takes advantage of the difference in the half-lives of ${ }^{10} \mathrm{Be}(1.4 \mathrm{Ma})$ and ${ }^{26} \mathrm{Al}(0.7$ Ma) to determine how long sediment has been buried. The basic premise of burial dating is that sediment is buried deep enough to avoid significant post-burial nuclide production (either zero or negligible) and has a simple history of exposure prior to burial (preferably longexposure time to reach steady state nuclide concentrations). After burial the nuclide concentrations decrease due to decay. Since ${ }^{26} \mathrm{Al}$ decays faster than ${ }^{10} \mathrm{Be}$, a burial age can be calculated by measuring both nuclides. Burial ages are determined based on the difference between the ${ }^{26} \mathrm{Al} /{ }^{10} \mathrm{Be}$ production ratio at the surface at the time of burial and the measured ratio of the buried sample. For most samples the surface ratio will be 6.75 (Balco et al., 2009), for slowly eroding landscapes this ratio may be somewhat lower (Granger, 2006). A burial age assumes one period of burial after exposure at the surface. But many periods of exposure and burial cannot strictly be ruled out making all burial ages minimum ages. Burial dating requires artificial outcrops that are at least $5 \mathrm{~m}$ deep (e.g., gravel pits). Several hundred grams of sand or $>50$ clasts are analyzed. In principle the age of a deposit can be determined with a single sample. Several samples would be analyzed to strengthen the underpinning of the determined age (for details see Granger and Muzikar, 2001; Granger, 2006).

Isochron-burial dating is a variation of burial dating because the time elapsed, as reflected in the measured nuclide concentrations, is determined by the difference between the two halflives. In contrast to burial dating, several samples are required and an isochron is constructed. The several samples analyzed are either from a single stratigraphic horizon or in a depth sequence (within a meter or so of each other) but at depth within the deposit (for details see Balco and Rovey, 2008). The whole suites of samples, as they are from the same stratigraphic horizon, have the same post-burial history. But as they likely had different pre-burial exposure histories (hill slope, intermediate storage, transport), they have different inherited nuclide concentrations (Balco and Rovey, 2008; Erlanger et al., 2012; Balco et al., 2013). By determining ${ }^{10} \mathrm{Be}$ and ${ }^{26} \mathrm{Al}$ concentrations on several samples from the same horizon, postburial component can be modeled and ${ }^{26} \mathrm{Al} /{ }^{10} \mathrm{Be}$ ratio at the time of burial (initial ratio) can be calculated. The isochron-burial age is then calculated by using the initial and measured ratios. As pre-burial (inherited) nuclides accumulated according to the surface production rate ratio of $6.75,{ }^{26} \mathrm{Al}$ concentrations vs. ${ }^{10} \mathrm{Be}$ concentrations for all samples should fall on a line. After burial, the concentrations fall again on a line, whose slope is controlled by the difference in the decay rates. The difference between the two lines (isochrons) gives the burial age (for details see Balco and Rovey, 2008; Erlanger et al., 2012; Balco et al., 2013). For isochronburial dating, several individual fist-sized clasts (ideally of various quartz-bearing lithologies) 
or sediment samples (sand or $>50$ clasts) are collected along a single stratigraphic horizon. Another version of isochron-burial dating is appropriate for dating of sand or $>50$ clasts from different depths in a deposit. The difference between the measured ratio and the surface ratio for each sample is determined. In other words, a whole depth profile is burial dated. Note that this method is intended for a 'paleo-depth profile' below a buried soil layer, so an ancient buried exposed surface (Balco and Rovey, 2008). The main advantage of isochron-burial dating is that it is independent of erosional modification of the top surface of the deposit. This method is extremely promising but has been applied in only a few settings (Dunai, 2012).

\section{Kızılırmak terraces}

\subsection{Terrace descriptions and sampling}

In our study area 15 levels of river terraces (T1 to T15) were previously described in detail (Fig. 2; Doğan, 2011). The oldest terraces (T1 to T5) are only preserved in few localities and their regional correlations are rather difficult to establish and therefore were not taken into account in this study. We only briefly describe here morphological and sedimentological characteristics of the terraces where we could establish a meaningful correlation and could sample for cosmogenic dating purposes. We collected twenty-eight clasts and sediment samples (sand or $>50$ pebbles between 1 to $5 \mathrm{~cm}$ in diameter for each sample) from seven terraces belonging to stratigraphically five different terrace levels (T6, T8, T9, T12 and T13). The descriptions of the samples are given in Table 1. We followed the same sampling strategy for isochron-burial and burial dating as given in Erlanger et al., (2012).

The terrace T6 is described and sampled in two separate localities (Fig. 2). The first locality covers an area close to $1 \mathrm{~km}^{2}$ and is situated in a gravel pit near Sarıhıdır village where $\sim 12 \mathrm{~m}$ thick braided river deposits are quarried $\sim 100 \mathrm{~m}$ above the today's Kizilırmak at $\sim 1025 \mathrm{~m}$ a.s.1. (Table 1; Fig. 2b; G-G' cross-section in Fig. 3 and 4a-c). Most of the quartz pebbles are spherical and well-rounded and aligned in sets of crude through cross beddings (Fig. 4b,c). Although the overall content is gravely, few sand bars are also preserved. The uppermost part of the unit is covered by $\sim 2 \mathrm{~m}$ thick red overbank horizon overlain by $\sim 2 \mathrm{~m}$ thick fine-grained calcareous sediments (Fig. 4b). We collected three quartz clasts $(10-12 \mathrm{~cm}$ in diameter) and four sediment samples (2-3 $\mathrm{cm}$ in diameter) each totaling around $1 \mathrm{~kg}$ for burial and isochronburial dating from a depth of around $10 \mathrm{~m}$ (Sample suite TCAP-1; Table 1) (Fig. 4c).

The second locality is found to the east of Yüksekli village and is exposed as small patches parallel to the actual river course. The base of the terrace is at $\sim 80 \mathrm{~m}$ and its upper surface is at $\sim 90 \mathrm{~m}$ above the actual river with a total thickness reaching $\sim 10 \mathrm{~m}$ (A-A' cross-section in Fig. 3 and $4 d$ ). The surface of the terrace shows signs of erosion and is mainly composed of semi-rounded quartz pebbles. We collected one sediment sample (TCAP-6; quartz pebbles, 1$5 \mathrm{~cm}$ in diameter) at $980 \mathrm{~m}$ a.s.l. for ${ }^{10} \mathrm{Be}^{26}{ }^{26} \mathrm{f}$ for surface exposure dating (Table 1, Fig. 3 and $4 d)$.

The terrace T8 is located to the southeast of Avanos village. The base of the terrace is $\sim 67 \mathrm{~m}$ and its upper level is $\sim 73 \mathrm{~m}$ due to local erosion and is mainly composed of gravely sediments reaching $6 \mathrm{~m}$ in thickness (F-F' cross-section in Fig. 3 and 4e). Gravely sediments show imbrications, tabular cross bedding and small channel fills and represent a braided river 
channel environment. The channel deposits are overlain by $\sim 1 \mathrm{~m}$ thick overbank horizon at the sampling site. We collected one single quartz clast $(9 \mathrm{~cm}$ in diameter) and four sediment samples (2-3 cm in diameter) for isochron- burial dating (Sample suite TCAP-5; Table 1, Fig. $2,3$ and $4 \mathrm{e})$.

The terrace T9 is situated between Gülşehir and Avanos villages along the road, on both sides of the Kizilirmak (Fig. 2) and unconformably overlies Miocene red paleosoil clays that are quarried and used in Avanos village pottery factories. In its thickest part, the base is approximately at $\sim 50 \mathrm{~m}$ and the upper level is at $\sim 63 \mathrm{~m}$ above actual river that flows at $915 \mathrm{~m}$ a.s.l. (E-E' cross-section in Fig. 3 and 4f,g). Calcareous pebbles of few $\mathrm{cm}$ in diameter together with some quartz grains are arranged in trough cross beds. The upper surface of the terrace is composed of loose pebbles indicating ongoing erosion. We collected one sediment sample (AVA1-CN2) at $963 \mathrm{~m}$ a.s.1. for ${ }^{36} \mathrm{Cl}$ for surface exposure dating (Table 1, Fig. 3 and 4f,g).

The terrace T12 is present on both sides of the Kizilırmak Valley situated $\sim 3 \mathrm{~km}$ to the northwest of Gülşehir. At the first locality to the north of the river, the terrace deposit is composed of 2-3 m thick pebbly quartz deposits overlain by 7-10 $\mathrm{m}$ thick floodplain and alluvial sediments (D-D' cross-section in Fig. 3 and 4h). From the channel deposits containing $\mathrm{cm}$ size pebbles just below the floodplain mudstones on the terrace T12 at $20 \mathrm{~m}$ above and north of the Kizılirmak, we collected one sediment sample (TCAP-2; quartz pebbles, 1-5 cm in diameter) from a road-cut at around $10 \mathrm{~m}$ depth for burial dating (Table 1, Fig. 2a, 3 and 4h).

At the second locality near Gürüzlük Hill, the gravelly deposits of the terrace T12 and overlying $\sim 3 \mathrm{~m}$ thick fine-grained floodplain sediments are capped by the Tuzköy Basalt ( $\beta 3)$ Plateau dated to $403.4 \pm 10.2 \mathrm{ka}$ (Doğan, 2011). The basalt and fine-grained sediments contact is at $\sim 30 \mathrm{~m}$ above the current river (B-B' cross-section in Fig. 3 and $4 \mathrm{i}$ ). We collected six quartz clasts ( 7 to $15 \mathrm{~cm}$ in diameter; TCAP-4A to $4 \mathrm{~F}$ ) for isochron-burial dating from $2 \mathrm{~m}$ below the surface from natural outcrop of the terrace T12, under the $403.4 \pm 10.2 \mathrm{ka}$ old Tuzköy Basalt ( $\beta 3$ ) (Doğan, 2011) and $23 \mathrm{~m}$ above the current river (Table 1, Fig. 2, 3 and 4i).

The terrace T13 can be observed on both slopes of the valley (Fig. 2; C-C' cross-section in Fig. 3 and $4 \mathrm{j}, \mathrm{k}$ ) with an average thickness reaching $5 \mathrm{~m}$. The terrace is composed of quartz and chert pebbles (1-5 cm in size) and to a lesser extent limestone and basalt pebbles of different sizes. Moderate to well-rounded pebbles, imbrications, sand matrix supported through cross beds indicate deposition in a braided channel. The upper level of the terrace situated $\sim 15 \mathrm{~m}$ above of the current river, is capped by the western section of the Karniyarik Hill Basalt ( $\beta 4$ ) dated to $94.5 \pm 18.2 \mathrm{ka}$ (Doğan, 2011). In a gravel pit to the south of the river, we collected quartz pebbles, 1 to $3 \mathrm{~cm}$ in diameter, from nine different depth levels (TCAP$3 \mathrm{~A}$ to $3 \mathrm{H}$ ) for depth-profile dating (Table 1, Fig. 2, 3 and $4 \mathrm{j}, \mathrm{k}$ ).

\subsection{Sample preparation and analysis}

The samples were processed at the Surface Exposure Laboratory of the University of Bern for the analysis of cosmogenic ${ }^{10} \mathrm{Be},{ }^{26} \mathrm{Al}$ and ${ }^{36} \mathrm{Cl}$. Quartz was separated from the samples and 
purified following a modified version of the technique introduced by Kohl and Nishiizumi (1992). Cosmogenic ${ }^{10} \mathrm{Be}$ and ${ }^{26} \mathrm{Al}$ were extracted using the lab protocol described in Akçar et al., (2012) for accelerator mass spectrometric measurements (AMS) at the ETH tandem facility in Zurich (Kubik and Christl, 2010). Total Al concentrations of the samples were determined by inductively coupled plasma optical emission spectrometry (ICP-OES) at the Department of Chemistry and Biochemistry of the University of Bern. The weighted mean average of $(3.13 \pm 0.36) \times 10^{-15}$ was applied for the ${ }^{10} \mathrm{Be} /{ }^{9} \mathrm{Be}$ full process blank ratio.

The sample AVA1-CN2 was prepared for cosmogenic ${ }^{36} \mathrm{Cl}$ analysis following the sample preparation procedure described in Akçar et al., (2012) using isotope dilution (Elmore et al., 1997; Ivy-Ochs et al., 2004; Desilets et al., 2006). Major and trace elements were measured at SGM Mineral Services, Toronto, Canada (Appendix 1). Due to the isotope dilution technique (Synal et al., 1997; Ivy-Ochs et al., 2004), total $\mathrm{Cl}$ and ${ }^{36} \mathrm{Cl}$ concentrations were determined from one target at the ETH AMS facility. Sample ratio of ${ }^{36} \mathrm{Cl} /{ }^{35} \mathrm{Cl}$ was normalized to the ETH internal standard $\mathrm{K} 382 / 4 \mathrm{~N}$ with a value of ${ }^{36} \mathrm{Cl} /{ }^{35} \mathrm{Cl}=17.36 \times 10^{-12}$ (normalized to the Nishiizumi standard in 2009) while the stable ${ }^{37} \mathrm{Cl} /{ }^{35} \mathrm{Cl}$ ratio was normalized to the natural ratio ${ }^{37} \mathrm{Cl} /{ }^{35} \mathrm{Cl}=31.98 \%$ of $\mathrm{K} 382 / 4 \mathrm{~N}$ standard and the machine blank.

Local production rates were calculated with CRONUS-Earth online calculator of Balco et al., (2008; http://hess.ess.washington.edu/math/) using wrapper script 2.2, main calculator 2.1, constants 2.2.1 and muons 1.1 according to constant Lal (1991) / Stone (2000) scheme. For the age calculations, a production rate of cosmogenic ${ }^{10} \mathrm{Be}$ due to spallation, at sea level-high latitude (SLHL), of $4.49 \pm 0.39$ atoms $/ \mathrm{gSiO}_{2}$. a and $\mathrm{a}^{26} \mathrm{Al} /{ }^{10} \mathrm{Be}$ production ratio of 6.75 were used (CRONUS calculator update from v. 2.1 to v. 2.2 published by Balco in October 2009). A SLHL cosmogenic ${ }^{36} \mathrm{Cl}$ production rate of $48.8 \pm 1.7$ atoms ${ }^{36} \mathrm{Cl} \mathrm{g}(\mathrm{Ca}){ }^{-1}$. a ${ }^{-1}$ from $\mathrm{Ca}$ spallation was applied (Stone et al., 1996). For production through muon capture, we considered a SLHL rate of $5.3 \pm 0.5^{36} \mathrm{Cl} \mathrm{g}(\mathrm{Ca})^{-1}$. $\mathrm{a}^{-1}$ (Stone et al., 1996, 1998). Based on Liu et al., (1994) and Phillips et al., (2001), we used a rate of $760 \pm 150$ neutrons. $\mathrm{g}^{-1} \cdot \mathrm{a}^{-1}$ to calculate production of ${ }^{36} \mathrm{Cl}$ due to capture of thermal and epithermal neutrons (for details see Alfimov and Ivy-Ochs, 2009). For burial and isochron-burial dating, density of the sediments was taken as $1.8 \mathrm{~g} / \mathrm{cm}^{3}$. For surface exposure dating, density of quartz pebbles was $2.6 \mathrm{~g} / \mathrm{cm}^{3}$ and of calcareous pebbles $2.4 \mathrm{~g} / \mathrm{cm}^{3}$, respectively. An exponential attenuation length of $160 \mathrm{~g} / \mathrm{cm}^{2}$ is considered after Gosse and Phillips (2001). A half-life of $1.39 \mathrm{Ma}$ for ${ }^{10} \mathrm{Be}$ (Korschinek et al., 2010; Chmeleff et al., 2010), 0.71 Ma for ${ }^{26} \mathrm{Al}$ (Norris et al., 1983; Nishiizumi, 2004), and $0.301 \mathrm{Ma}$ for ${ }^{36} \mathrm{Cl}$ (Zreda et al., 1991) were used. We assumed mean life of $2.005 \mathrm{Ma}$ for ${ }^{10} \mathrm{Be}$ and of $1.02 \mathrm{Ma}$ for ${ }^{26} \mathrm{Al}$ in our calculations.

\section{Results}

\subsection{Cosmogenic isochron-burial dating of the strath terraces}

In Table 2, the amount of dissolved quartz, ${ }^{9} \mathrm{Be}$ carrier, ${ }^{10} \mathrm{Be}$ concentration with absolute and relative uncertainties, total $\mathrm{Al}$ concentration, ${ }^{26} \mathrm{Al}$ concentration with absolute and relative uncertainties, and ${ }^{26} \mathrm{Al}$ vs ${ }^{10} \mathrm{Be}$ ratio for each sample are given. The amount of dissolved rock, ${ }^{36} \mathrm{Cl}$ carrier, total $\mathrm{Cl}$ concentration, major and trace element data, ${ }^{36} \mathrm{Cl}$ concentration, local production rate and apparent exposure age for sample AVA1-CN2 with $1 \sigma$ uncertainty is presented in Appendix 1. 
$\mathrm{A}{ }^{26} \mathrm{~A} /{ }^{10} \mathrm{Be}$ ratio of $5.68 \pm 0.40 \mathrm{ka}$ was determined for the sample TCAP-2. The nuclide concentrations for this sample correspond to a pre-burial erosion rate of $\sim 35 \mathrm{~m} / \mathrm{Ma}$ and a surface ratio of 6.65 based on steady-state erosion. The difference between this surface ratio and the measured ratio is a measure of the period of burial. As this sample is deeply buried, i.e. negligible post-burial accumulation of ${ }^{10} \mathrm{Be}$ and ${ }^{26} \mathrm{Al}$, we calculated a simple burial age of $340 \pm 40 \mathrm{ka}$ for the terrace T12 in the north of the Kizılırmak based on Granger et al., (1997) and Granger and Muzikar (2001) (Table 3).

For the rest of the samples we calculated isochron-burial ages (Balco and Rovey, 2008) following the calculation steps as described in detail in Erlanger et al., (2012). We first plotted measure ${ }^{26} \mathrm{Al}$ concentration versus measured ${ }^{10} \mathrm{Be}$ concentration with $1 \sigma$ uncertainty for each sample suite and plotted a regression line. Using the slope of this line, in other words, the offset from the surface ratio line, we calculated an initial burial age estimate. While the intercept of these two lines gives the post-burial component of ${ }^{10} \mathrm{Be}$ and ${ }^{26} \mathrm{Al}$. Next, based on the initial burial age estimate, we calculated inherited nuclide concentrations. These are corrected for isotope decay again based on the initial burial time estimate. The decaycorrected inherited ${ }^{10} \mathrm{Be}$ concentration was used to determine the burial erosion rate for each sample, which in turn are used to calculate an initial (at the surface before burial) ${ }^{26} \mathrm{Al} /{ }^{10} \mathrm{Be}$ ratio. The ratio of the initial and surface ratios (linearization factor of Erlanger et al., 2012) is used to correct for post-burial nuclide production. Linearized ${ }^{10} \mathrm{Be}$ concentrations were then plotted against measured ${ }^{26} \mathrm{Al}$ concentrations. A line was fit to the plot and the slope of this fit was used to calculate the isochron-burial age. The described process was iterated until convergence. For two of the terraces (T13: TCAP-3 and T12: TCAP-4), prior to the above calculations, it was necessary to correct for nuclides accumulated after burial by basalt flows at $\sim 404 \mathrm{ka}$ and $\sim 95 \mathrm{ka}$, respectively. For these calculations, we assumed $2.4 \mathrm{~g} / \mathrm{cm}^{3}$ density for basalt and an erosion rate of $5 \mathrm{~mm} / \mathrm{ka}$ (Sims et al., 2007). In these two cases, the determined isochron burial age is the time before eruption of the basalt onto the terrace. Therefore, the age of the basalt is added to the determined burial ages for those terraces.

For the terrace T6, we calculated an initial slope of $2.77 \pm 0.33$ and an age estimate of $1890 \mathrm{ka}$ based on the results from five samples since ${ }^{26} \mathrm{Al}$ measurements in two samples from this set did not yield enough current during the AMS measurements. Isochron-burial age calculations using these gave an isochron slope of $2.78 \pm 0.13$ and age of $1890 \pm 100$ ka (Table 3 and Fig. $5 a)$.

Although we sampled the terrace T13 for depth-profile dating, the measured concentrations in sample set TCAP-3 (Fig. 5b), indicate very high inheritance, which is the perfect pre-requisite for isochron-burial dating. Therefore, we calculated an isochron age using the uppermost six samples in the set. Before this, we corrected measured concentrations for a basalt cover of 3 $\mathrm{m}$ for the last $94.5 \pm 18.2 \mathrm{ka}$ based on the ${ }^{40} \mathrm{Ar} /{ }^{39} \mathrm{Ar}$ ages from Doğan (2011). These yielded a decrease of $2-4 \%$ in ${ }^{10} \mathrm{Be}$ and $5-7 \%$ in ${ }^{26} \mathrm{Al}$ concentrations. In a classical isochron-burial age calculation, the post-burial component will be the same for all samples as they stem from the same depth. In our case, they stem from different depths but still from the same layer. Therefore, we calculated different post-burial components for each sample depending on depth. For the terrace T13, the slope of initial fit was $6.32 \pm 1.14$ and the initial age estimate 139 ka prior to burial by basalt flow. The isochron fit gave a slope of $6.57 \pm 1.19$ and age of 
$60 \pm 10 \mathrm{ka}$. Finally, we calculated an isochron age of $160 \pm 30 \mathrm{ka}$ by adding the $94.5 \pm 18.2 \mathrm{ka}$ of basalt-burial (Table 3 and Fig. 5c).

We followed the same strategy for TCAP-4 samples from the terrace T12, south of the river. The corrections of measured concentrations for a basalt cover of $3 \mathrm{~m}$ for the last $403.4 \pm 10.2$ ka based on the ${ }^{40} \mathrm{Ar} /{ }^{39} \mathrm{Ar}$ ages (Doğan, 2011) ended in decreases of 9-16\% for ${ }^{10} \mathrm{Be}$ and 21 $24 \%$ for ${ }^{26} \mathrm{Al}$. We determined the slope of the initial regression as $3.23 \pm 0.10$ and the age estimate as $1560 \mathrm{ka}$, and then we regressed the isochron fit with a slope of $3.93 \pm 0.16$. Using this, we calculated an isochron age of $1160 \pm 80 \mathrm{ka}$ prior to $403.4 \pm 10.2 \mathrm{ka}$ basalt cover. The burial age of this terrace was determined as 1560 $\pm 80 \mathrm{ka}$ (Table 3 and Fig. 5d). The sample TCAP-4F was excluded in these calculations since it did not yield enough current during the AMS measurements.

As the $\mathrm{Al}$ fraction of three of five from TCAP-5 samples was lost during processing, we were only able to report an estimate of isochron-burial age using two valid data points. This gave an estimate of $1360 \mathrm{ka}$ of burial for the terrace T8 (Table 3 and Fig. 5e).

Surface amalgamated pebble samples from T6 (TCAP-6) and T9 (AVA1-CN2) yielded minimum exposure ages of $35.6 \pm 3.3 \mathrm{ka}$ and $22.7 \pm 1.4 \mathrm{ka}$, respectively (Table 3 ). Neither erosion nor snow corrections were included in the calculation of these ages, as we did not use them in our fluvial incision calculations. It is important to note that surface exposure dating of the fluvial terrace treads is a difficult task as natural erosion can severely decrease the true ages.

\subsection{Cosmogenic isochron-burial ages vs. ${ }^{40} \mathrm{Ar} /{ }^{39} \mathrm{Ar}$ ages}

To confirm the reliability of our cosmogenic isochron-burial ages, we compared them with higher or lower terrace ages and ${ }^{40} \mathrm{Ar} /{ }^{39} \mathrm{Ar}$ ages from the basalt lava flows, determined at Vrije University Geoscience Laboratory (Amsterdam) (Schneider et al., 2009; Doğan, 2011), intercalated with fluvial terrace deposits of the Kiz1lirmak Valley. Accordingly, our terrace T6 $(1890 \pm 100 \mathrm{ka})$ is lower than $\beta 1$ basalt lava flow $(1989.4 \pm 38.9 \mathrm{ka})$, the terrace T8 $(1360 \mathrm{ka})$ is higher than $\beta 2$ basalt lava flow $(1228.2 \pm 46.4 \mathrm{ka})$, the terrace T12 $(340 \pm 4.0 \mathrm{ka})$ is lower than $\beta 3$ basalt lava flow $(403.4 \pm 10.2 \mathrm{ka})$, and the terrace T13 $(160 \pm 30 \mathrm{ka})$ is lower than $\beta 4$ basalt lava flow $(94.5 \pm 18.2 \mathrm{ka})$. Therefore, we believe that this very close correlation with the morphostratigraphy, show the reliability of our cosmogenic ages.

The isochron-burial age of $1560 \pm 80 \mathrm{ka}$ from the southern T-12 terrace (TCAP-4), under the Tuzköy Basalt ( $\beta 3$ ), does not fit to the reconstructed chronostratigraphy of this study (Fig. 2 and 3). We suggest that this is an unpaired terrace. The back and forth switches in the river course within its bed, while incising through the previously deposited alluvium, may result in unpaired terraces, which cannot be correlated with the terrace on the opposite side of the river (Burbank and Anderson, 2001). These are unpredictable sediment packages at any location and the reconstruction of their downstream geometry may be difficult (Merritts et al., 1994). Unpaired terraces are not practical for the determination of long-term patterns of tectonic deformation (Burbank and Anderson, 2001). Therefore, we exclude this terrace from further discussion in this paper.

\subsection{Incision rates from the strath terraces}


To calculate incision rates of individual strath terraces we divided terrace heights by their isochron-burial ages. Their incision rates range from $0.053 \pm 0.03$ to $0.081 \pm 0.02 \mathrm{~mm} / \mathrm{yr}(53 \pm 3$ to $81 \pm 2 \mathrm{~m} / \mathrm{Ma}$ ) (Table 4$)$.

To calculate mean incision rates including all dated strath terrace levels, we plotted the burial ages against the height of the strath terraces with respect to present level of the Kizilirmak. The regression lines for the long-term incision rates (since $1.9 \mathrm{Ma}$ ) according to present level yield $0.051 \pm 0.01 \mathrm{~mm} / \mathrm{yr}(51 \pm 1 \mathrm{~m} / \mathrm{Ma}$ ) (Fig. 6). On the other hand, Doğan (2011) documented that the Kizilirmak used to flow $18 \mathrm{~m}$ lower than today $18 \mathrm{ka}$ ago. Therefore, we also calculated Kizilırmak mean incision rate with respect to its paleo-level (18 ka ago) that gives $0.06 \pm 0.003 \mathrm{~mm} / \mathrm{yr}(60 \pm 3 \mathrm{~m} / \mathrm{Ma})$.

\subsection{Long-term denudation rate derived from relief inversion of a basaltic lava flow}

The Quaternary basalt lava flows, changing between $\sim 2$ to $5 \mathrm{~m}$ in thickness, are very common in the CVP (Doğan, 2011). The Evren Ridge Basalt ( $\beta 1)$ in the Kizılırmak Valley is one of them and a key geomorphic datum to constrain long-term denudation and incision rate for this part of the CAP (Fig. 7). The ridge is a basaltic lava flow that filled a paleo-valley of a tributary of the Kizllırmak. The ${ }^{40} \mathrm{Ar} /{ }^{39} \mathrm{Ar}$ ages of the flow yield $2 \mathrm{Ma}$ (Doğan, 2011; Aydar et al., 2013). Today the valley is eroded and the basaltic lava flow formed a $18 \mathrm{~km}$ long ridge whose top surface is now 100-110 m higher than its adjacent topography indicating relief inversion. The height of the ridge provides minimum depth of the eroded material and allow us to estimate minimum rate of denudation for the last $2 \mathrm{Ma}$. Accordingly, we estimated 0.05$0.06 \mathrm{~mm} / \mathrm{yr}$ minimum denudation rate for this part of the plateau which strongly refers to our long-term incision/rock uplift rates $(0.051 \pm 0.01 \mathrm{~mm} / \mathrm{yr})$ derived from fluvial strath terraces. Additionally, the bottom of the basalt lava indicates the base of the paleo-valley floor which is now $135 \mathrm{~m}$ above the modern course of the paleo-valley (Özdere River in Fig. 2). That yields $0.07 \mathrm{~mm} / \mathrm{yr}$ mean incision rate for the last $2 \mathrm{Ma}$ which is also similar to the mean incision rate of the Kizilirmak. Similarity between the denudation and incision rates might imply erosional flux steady-state conditions that are compatible with low-relief flat-lying topography within the CAP.

\section{Discussion}

\subsection{Tectonic vs. climatic forcing in terrace formation}

Climatic fluctuations and/or tectonic factors can be responsible for the fluvial incision and/or terrace formation. Some of these factors include uplift or subsidence, changes in discharge and sediment load, stream capture and climate controlled base-level fluctuations (e.g., Hancock and Anderson, 2002; Vandenberghe, 2003; Bookhagen and Strecker, 2012). It is now readily accepted that the staircase morphology observed on fluvial terraces develops in response to regional uplift as without the vertical movement of the crust, rivers would flow more or less at the same relative level (Antoine et al., 2000; Bridgland, 2000; Maddy et al., 2001; Bridgland and Westaway, 2008; Wegmann and Pazzaglia, 2009).

The CAP is structurally characterized by normal faults with strike slip components (Şengör et al., 1985; Genç and Yürür, 2010). The Tuz Gölü, Salanda, Gülşehir and Tuzköy Faults are active structures having surface expressions in the study area (Fig. 1 and 2). In the west of the 
Kızılırmak, the Tuz Gölü Fault is one of the major structures of Central Anatolia (Görür et al., 1984; Çemen et al., 1999; Fernández-Blanco et al., 2013). The vertical slip rates along the fault derived from displaced strata of ignimbrites and lacustrine limestone yield from 0.05 to $0.08 \mathrm{~mm} / \mathrm{yr}$ for the last $5 \mathrm{Ma}$ (Kürçer and Gökten, 2012; Özsayın et al., 2013). These rates are very similar to our incision/rock uplift rates obtained from the Kiz1lirmak terraces. The river is located on the footwall block of the fault and flows very close to the fault especially in the near north of the study area. Nevertheless, the wavelength of the uplift associated with the Tuz Gölü Fault is very short and therefore similar rates might imply a response to regional strain rather than the impact of the fault on the incision rates when we consider its distance to the study area. Other structures, such as Salanda, Tuzköy and Gülşehir Faults have limited expressions compared to Tuz Gölü Fault and they operate only along the Kizılırmak Valley. The river flows parallel along the hanging-wall blocks (down-thrown block) of the faults and therefore its incision is negatively affected and even decelerated by the activity of these faults. Nonetheless, individual terraces such as Tuzköy Basalt ( $\beta 3)$ and Karniyarık Hill Basalt ( $\beta 4)$ might have been partly uplifted by these faults but their impacts are very limited. In fact, the flights of the Kizılirmak terraces are also observed elsewhere. Further north, until the North Anatolian Fault, Akkan (1970) documented several flights of terraces along the Kiz1lirmak as geomorphic markers of regional incision. We therefore believe that incision is not only restricted to our study area, implying a larger scale impact rather than influence of local tectonic structures.

Because the Quaternary period is characterized by alternating high frequency glacialinterglacial cycles it is highly likely that climatic forcing also played a major role in the development of the landscape in the CAP. Unfortunately, error margins and uncertainties of our burial ages are too large to allow us to precisely correlate timing of incisions with climatic fluctuations.

Doğan (2010) studied an $18 \mathrm{~m}$ long sediment core (KP-S3, Fig. 2a) taken from the actual river bed of Kizilırmak in our study area. The results indicate that the main incision phase occurred during the Last Glacial Maximum (LGM) ( 19 to $21 \mathrm{ka}$ ) as a response to climatic changes. Severe floods probably occurred during the LGM due to a decrease in evapotranspiration and infiltration, a near doubling of precipitation rates, and up to $\sim 10{ }^{\circ} \mathrm{C}$ cooler temperatures easing bedrock downcutting (Sarıkaya et al., 2009). Indeed, recent data indicates the presence of LGM glaciers in nearby regions (e.g., Sarıkaya et al., 2009) and a decline in permanent snowline changing between 1900 to $2700 \mathrm{~m}$ in the CAP (see Table 30.1 in Sarıkaya et al., 2011). The severity of the LGM (Akçar et al., 2007, 2014; Sarıkaya et al., 2008, 2014; Sarıkaya et al., 2011 and references therein) and even younger glaciations (Zreda et al., 2011) in Turkey are now widely demonstrated. We can therefore assume that fluvial downcutting that created the stepwise terrace topography observed in our study area, was an effective agent during Quaternary glacial periods. In such a scenario the fluvial aggradation and the development of the terraces would occur during the cold-warm climate transition times as well as warm periods (Doğan, 2010, 2011). Correlations between Marine Isotope Stages (MIS) and terrace formation times are also reported from other parts of the world (e.g., Pazzaglia and Brandon, 2001; Benedetti et al., 2000; Schildgen et al., 2012a). 
Our data set, together with previous studies by Doğan (2011) and Aydar et al., (2013), allow us to discuss the uplift rates within the CAP. Our results imply that the K1z1lirmak has been incising its valley since $1.9 \mathrm{Ma}$ with a mean rate of $0.051 \pm 0.01 \mathrm{~mm} / \mathrm{yr}$. Doğan (2011) also previously calculated the Kizilırmak vertical incision rates to be $0.08 \mathrm{~mm} / \mathrm{yr}$ averaged over the last $2 \mathrm{Ma}$ based on relative stratigraphy of fifteen terrace sequences and four basalt ${ }^{40} \mathrm{Ar} /{ }^{39} \mathrm{Ar}$ ages. By assigning the terrace ages to the DSDP-607 MIS graphic (Raymo, 1992) (his Fig. 17), Doğan (2011) also proposed tentative ages to the Kızılırmak terraces (his Table 2: $\mathrm{T} 13=289 \mathrm{ka}, \mathrm{T} 12=404 \mathrm{ka}, \mathrm{T} 8=811 \mathrm{ka}, \mathrm{T} 6=995 \mathrm{ka})$. These ages are 5 to $40 \%$ lower than our cosmogenic age results, summarized in Table 3. Doğan (2011) results also showed that the incision rate between $\sim 1989 \mathrm{ka}$ and $\sim 1228 \mathrm{ka}(0.04 \mathrm{~mm} / \mathrm{yr})$ increased well above the mean value $(0.08 \mathrm{~mm} / \mathrm{yr})$ between $\sim 1228 \mathrm{ka}$ and $\sim 404 \mathrm{ka}$, to $0.12 \mathrm{~mm} / \mathrm{yr}$. The rate fell to 0.08 $\mathrm{mm} / \mathrm{yr}$ between $\sim 404 \mathrm{ka}$ and $\sim 95 \mathrm{ka}$ and then to $0.05 \mathrm{~mm} / \mathrm{yr}$ from $\sim 95 \mathrm{ka}$ to the present.

For much longer time scales (since $5 \mathrm{Ma}$ ), Aydar et al., (2013) calculated the incision rates by using horizontally emplaced and radiometrically well-constrained Neogene-Quaternary ignimbrites of CVP (Aydar et al., 2012) intercalated with lava flows and fluvio-lacustrine sediments. Their results indicate that the incision rate was $0.12 \mathrm{~mm} / \mathrm{yr}$ between $5 \mathrm{Ma}$ and 2.5 $\mathrm{Ma}$, and that in the last $2.5 \mathrm{Ma}$, it slowed down to $0.04 \mathrm{~mm} / \mathrm{yr}$. As these rates cover very large time spans, they do not indicate variations through time but rather long-term average rates.

As a result, the longer or relatively shorter time scale incision rates are consistent with slow Quaternary uplift rates that we observe within the CAP indicating the persistent stability of the landscape. Therefore, it is now clear that the CAP not only witnessed less Quaternary surface uplift but also the uplift rates were much slower $(0.051 \pm 0.01 \mathrm{~mm} / \mathrm{yr}$ since $1.9 \mathrm{Ma})$ compared to the northern and southern margins (Fig. 8; e.g., Schildgen et al., 2012a,b; Cosentino et al., 2012a,b; Y1ldırım et al., 2013a,b) that we discuss below.

\subsection{Spatial variations of surface uplift rates along the CAP}

Several scientific papers resulting from Vertical Anatolian Movement Project (2008-2012) of Topo Europe initiative helped to improve our understanding of the surface uplift rates of the CAP since $8 \mathrm{Ma}$ (e.g., special volume by Çiner et al., 2013). A recent review by Schildgen et al., (2013) links the mechanisms behind the plateau uplift not only in the CAP but also in the Eastern Anatolian Plateau. Below, we compare our results from the CAP with either margin in order to elucidate the differential character of the uplift since the Quaternary (Fig. 8).

\subsubsection{Differential uplift between the northern margin and the CAP}

The northern margin corresponds to the Central Pontides, situated between the CAP and the Black Sea (Fig. 8). The northern margin has been interpreted as an actively deforming orogenic wedge between the North Anatolian Fault and the abyssal plain (Y1ldırım et al., 2011). The Kizilirmak flows all along the CAP and traverses the Central Pontides recording tectonic and climatic influences on the topography. Therefore, fluvial terraces along the Kizilırmak are key geomorphic markers to understand spatial and temporal variations of those influences.

Upon reaching the Black Sea, the Kizılirmak forms a delta plain and its paleo-levels are elevated at 20-30 m and 60-70 m above sea level (Akkan, 1970). These levels are interpreted 
as probably developed during Pleistocene sea-level highstands (Demir et al., 2004). Even though marine fossils are not found in these deltaic deposits, Bilgin (1963) described marine terraces further east at $7-8 \mathrm{~m}$ and at $25-30 \mathrm{~m}$ a.s.1. which contain fossil assemblages suggesting that these terraces probably developed during MIS 5e and MIS 5a. Based on its comparable altitude, the lower terrace of Kiz1lirmak paleo-delta at 20-30 m a.s.1. was most likely formed also during MIS 5e (125 ka), indicating an uplift rate of $0.24 \mathrm{~mm} / \mathrm{yr}$ (Demir et al., 2004). Therefore, the upper terrace was tentatively attributed to MIS 7 (240 ka) or MIS 9 (340 ka), with an uplift rate changing between $0.29 \mathrm{~mm} / \mathrm{yr}$ to $0.21 \mathrm{~mm} / \mathrm{yr}$ (Demir et al., 2004).

Further south, the Late Quaternary fluvial incision was estimated by using cosmogenic surface exposure dating of the fluvial terraces formed along the Gökırmak River, which is the biggest tributary of the Kizilirmak in the Central Pontides. The mean incision rate was calculated as $0.28 \mathrm{~mm} / \mathrm{yr}$ since $350 \mathrm{ka}$ (Yildirım et al., 2013b). That is very close to the coastal uplift rate derived from uplifted paleo-delta levels. In comparison to the northern margin of the plateau, our data set implies a $0.051 \pm 0.01 \mathrm{~mm} / \mathrm{yr}$ incision rate for the last 1.9 Ma. This reveals that the Kizllırmak incision rate is significantly slower in the CAP compared to its downstream reaches draining the Central Pontides. Higher incision rates are also compatible with higher relief within the northern margin in comparison to subtle and low relief topography of the CAP (Fig. 8). This might be a consequence of the large restraining bend of the North Anatolian Fault and accumulation of high strain in the north with respect to the CAP. We believe that higher incision rates are responses of the Kizılirmak to accumulation of higher strain in the north.

\subsubsection{Differential uplift between the southern margin and the CAP}

The southern margin corresponds to the Central Taurides, which arise between the Mediterranean Sea and the CAP (Fig. 8). Different from the northern margin, there is no river transversing from the CAP to the southern margin. Nevertheless, the presence of Neogene marine deposits and flights of fluvial terraces within the Göksu River basin that drain the Central Taurides allow us to compare incision rates between the southern margin and the CAP.

The southern margin experienced changing and differential uplift rates since $8 \mathrm{Ma}$. Schildgen et al., (2012a) used published and newly described biostratigraphic data from $\sim 2 \mathrm{~km}$ uplifted marine sediments in Mut Basin to calculate average uplift rates of 0.25 to $0.37 \mathrm{~mm} / \mathrm{yr}$ between 8 and $5.45 \mathrm{Ma}$, and 0.72 to $0.74 \mathrm{~mm} / \mathrm{yr}$ after 1.66 to $1.62 \mathrm{Ma}$. They also used Göksu River terraces in the Mut Basin to show average incision rates of 0.52 to $0.67 \mathrm{~mm} / \mathrm{yr}$ between 25 to $130 \mathrm{ka}$. Together with the terrace abandonment ages, their data imply 0.6 to $0.7 \mathrm{~mm} / \mathrm{yr}$ uplift rates from 1.6 Ma to the present and were interpreted to reflect multi-phased uplift of the southern plateau margin, rather than steadily increasing uplift rates (Schildgen et al., 2012a). Similarly, Cosentino et al., (2012a) using nannofossil, ostracod, planktic foraminifera and reverse polarity of the samples collected from Miocene marine sediments capping the southern margin in Mut-Ermenek Basin calculated an average uplift rate of 0.24 to 0.25 $\mathrm{mm} / \mathrm{yr}$ since $8 \mathrm{Ma}$.

In comparison to the southern margin our data set implies $0.051 \pm 0.01 \mathrm{~mm} / \mathrm{yr}$ mean incision rates for the last $1.9 \mathrm{Ma}$ (Fig. 8). These rates reveal that the Kizılırmak has significantly 
slower incision rates within the CAP compared to the southern margin and indicate different geodynamic conditions in the CAP with respect to the southern margin (Fig. 8). In fact, the minimum elevation along the swath profile across the CAP from southern to northern margin indicates a continental scale tilting from south to north, most probably as a result of differential surface uplift long the CAP. We discuss below possible mechanisms of this differential uplift across the CAP.

\subsection{Mechanisms of uplift}

Several mechanisms can be candidates for the uplift that characterizes the large plateaus around the world (e.g., Molnar et al., 1993; Allmendinger et al., 1997; Garcia-Castellanos, 2006; Gögüş and Pysklwec, 2008; Şengör et al., 2003, 2008). Various mechanisms for the uplift of the CAP are also recently proposed (e.g., Schildgen et al., 2012a, 2013, 2014; Y1ldirım et al., 2013a,b). For instance, in their multi-phased scenario for the southern margin, Schildgen et al., (2012a) suggested a first phase of $\sim 0.8 \mathrm{~km}$ uplift since $8 \mathrm{Ma}$, and a second phase of rapid uplift starting at $\sim 1.6 \mathrm{Ma}$ that still continues today, which increased the margin elevation by $\sim 1.2 \mathrm{~km}$. As a potential mechanism for the first phase they proposed the slab break-off (Cosentino et al., 2012a) and/or delamination of the lithospheric mantle (Bartol et al., 2011, 2012). The second and rapid phase of uplift (since Quaternary) is attributed to the modified mantle flow patterns that followed the slab break-off or Early to Middle Pleistocene collusion of the Eratosthenes Seamount with the trench to the south of Cyprus (Robertson, 1998; Schattner, 2010). Based on recent tomography studies that show an intact Cyprus slab under the CAP, Fernández-Blanco et al., (2012) proposed an alternative, suggesting that sediment accretion and deposition at the central Cyprus arc created growth of the Anatolian upper plate including the associated forearc basin system. In such a scenario, crustal thickening would lead to higher temperatures at the base of the crust, thermal weakening and thus viscous deformation. This viscous deformation would drive subsequent surface uplift of the modern Taurus Mountains in the southern margin.

For the northern margin, it has been suggested that the broad restraining bend of the North Anatolian Fault has led to the development of an active orogenic wedge, since Late Miocene to Early Pliocene, that drives crustal thickening, active internal shortening and uplift in the Central Pontides (Y1ldırım et al., 2011; 2013a, b).

Contrary to the southern and northern margins, the Quaternary uplift rates in the CAP are much slower as our data from Kizilırmak terraces, Evren Ridge Basalt ( $\beta 1)$ denudation rate and basalt ages from previous studies (e.g., Doğan, 2011) indicate. Y1ldırım et al., (2013b) relates this situation to the fact that the northward-flowing K1z1lurmak is currently in a transient state, with upstream portions of the river not yet adjusted to the faster recent uplift rates.

Provided that the normal faulting is a consequence of the plateau uplift, as observed in Tibet (Armijo et al., 1986) and in the Altiplano (Montero Lopez et al., 2010), delamination of the lithospheric mantle in the southern margin and the modified mantle flow patterns that followed the slab break-off (Schildgen et al., 2012a), seems to be the best-suited model for the uplift in the CAP characterized by an extensional regime. 
On the other hand, contemporaneous development of calc-alkaline and alkaline volcanism is characteristic in the CVP during the Quaternary (Aydar et al., 2012). Moreover, a slight tendency toward peralkaline nature of rhyolitic volcanism during the Middle and Late Pleistocene (200 to $150 \mathrm{ka}$ and 25 to $20 \mathrm{ka}$; Schmitt et al., 2011) was observed by Çubukcu et al., (2010). This change in geochemistry can be attributed to the decreasing influence of crustal contamination and/or subduction (Innocenti et al., 1975; Schildgen et al., 2013).

\section{Conclusions}

Our cosmogenic burial and isochron-burial ages from flights of fluvial terraces in the Cappadocia section of the Kiz1lırmak reveal incision induced by ongoing rock uplift for at least the last 1.9 Ma in the Central Anatolian Plateau. The spatial distribution of the strath terraces and their relationship with local faults imply that the large-scale lithospheric processes rather than local tectonic structures have driven this rock uplift. According to the present level of the Kizilirmak the mean rock uplift rate for this part of the plateau yielded $0.051 \pm 0.01 \mathrm{~mm} / \mathrm{yr}(51 \pm 1 \mathrm{~m} / \mathrm{Ma})$. Our mean denudation rate from an inverted basalt valley fill also yields $0.05-0.06 \mathrm{~mm} / \mathrm{yr}$, which is in harmony with the mean rock uplift rate, indicating steady-state conditions in the study area. Given these factors, the uplift rate in the CAP has been considerably slower (up to 5 to 10 times) than its northern and southern margins respectively.

\section{Acknowledgments}

This work is part of the Vertical Anatolia Movements Project (VAMP), supported by the TOPOEUROPE initiative of the European Science Foundation and funded by the Scientific and Technological Research Council of Turkey (TÜBİTAK; Project 107Y333) and the Surface Exposure Dating Laboratory at the University of Bern (Switzerland). We are grateful to Esther Haudenschild, Regina Reber and Anne Claude (University of Bern), for their help in the sample preparation. We would also like to thank the Zürich AMS Facility operated by the Swiss Federal Institute of Technology. We thank to all VAMP participants for stimulating discussions and Daniel Melnick (Potsdam University) and Alkor Kutluay (Hacettepe University) for their help in DGDP measuring of the terrace T9. We are also grateful to Darryl Granger at the Purdue University for his help and suggestions during the revision of this manuscript. We thank two anonymous reviewers for their very helpful and constructive comments. We also appreciate English proof reading by Kevin McClain.

\section{References}

Akçar, N., Yavuz, V., Ivy-Ochs, S., Kubik, P.W., Vardar, M., Schlüchter, C., 2007. Paleoglacial records from Kavron Valley, NE Turkey: Field and cosmogenic exposure dating evidence. Quaternary International 164-165, 170-183.

Akçar, N., Tikhomirov, D., Özkaymak, C., Ivy-Ochs, S., Alfimov, V., Sözbilir, H., Uzel, B., Schlüchter, C., 2012. Cl-36 exposure dating of paleoearthquakes in the Eastern Mediterranean: First results from the western Anatolian Extensional Province, Manisa fault zone, Turkey. Geological Society of America Bulletin 124, 1724-1735. 
Akçar, N., Yavuz, V., Ivy-Ochs, S., Reber, R., Kubik, P.W., Zahno, C., Schlu $\square$ chter, C., 2014. Glacier response to the change in atmospheric circulation in the eastern Mediterranean during the Last Glacial Maximum. Quaternary Geochronolgy 19, 27-41.

Akgün, F., Kayseri, M.S., Akkiraz, M.S., 2007. Palaeoclimatic evolution and vegetational changes during the Late Oligocene-Miocene period in Western and Central Anatolia (Turkey). Palaeogeography Palaeoclimatology Palaeoecology 253, 56-90.

Akkan, E., 1970. Kızılırmak vadisinin jeomorfolojisi. Ankara Üniversitesi Dil ve TarihCoğrafya Fakültesi Yayınları 191, 1-158.

Alfimov, V., Ivy-Ochs, S., 2009. How well do we understand production of (36)Cl in limestone and dolomite? Quaternary Geochronology 4, 462-474.

Allmendinger, R.W., Jordan, T.E., Kay, S.M., Isacks, B.L., 1997. The evolution of the Altiplano-Puna plateau of the Central Andes. Annual Review of Earth and Planetary Sciences 25, 139-174.

Antoine, P., Lautridou, J.-P., Laurent, M., 2000. Long-term fluvial archives in NW France: response of the Seine and Somme rivers to tectonic movements, climatic variations and sea-level changes. Geomorphology 33, 183-207.

Antoine, P., Munaut, A.-M., Limondin-Lozouet, N., Ponel, P., Duperon, J., Duperon, M., 2003. Response of the Selle River to climatic modifications during the Late glacial and Early Holocene (Somme Basin-Northern France). Quaternary Science Reviews 22, 2061-2076.

Armijo, R., Tapponnier, P., Mercier, J.L., Han, T-L., 1986. Quaternary extension in southern Tibet: Field observations and tectonic implications. Journal of Geophysical Research 91, B14, 13803-13872.

Atabey, E., 1989. Aksaray-H18-H19 Quadrangle, 1:100000 Scale Geological Map and Explanatory Text. Mineral Research and Exploration Institute of Turkey (MTA) Publications [in Turkish with English abstract].

Aydar, E., Schmitt, A.K., Çubukçu, H.E., Akın, L., Ersoy, O., Şen, E., Duncan, R.A., Atıc1, G., 2012. Correlation of ignimbrites in the central Anatolian volcanic province using zircon and plagioclase ages and zircon compositions. Journal of Volcanology and Geothermal Research 213-214, 83-97.

Aydar, E., Çubukçu, H.E., Şen, E., Akın, L., 2013. Central Anatolian Plateau, Turkey: incision and paleoaltimetry recorded from volcanic rocks. In: "Late Cenozoic Evolution of the Central Anatolia Plateau", Çiner, A., Strecker, M.R., Bertotti, G. (eds.), Turkish Journal of Earth Sciences 22, 691-714739-746.

Balco, B., Rovey, C.W., 2008. An isochron method for cosmogenic-nuclide dating of buried soils and sediments, American Journal of Science 308, 1083-1114.

Balco, G., Stone, J.O., Lifton, N.A., Dunai, T.J., 2008. A complete and easily accessible means of calculating surface exposure ages or erosion rates from Be-10 and Al-26 measurements. Quaternary Geochronology 3, 174-195. 
Balco, G., Soreghan, G.S., Sweet, D.E., Marra, K.R., Bierman, P.R., 2013. Cosmogenicnuclide burial ages for Pleistocene sedimentary fill in Unaweep Canyon, Colorado, USA. Quaternary Geochronology 18, 149-157.

Bartol, J., Govers, R., Wortel, M.J.R., 2011. The Central Anatolian Plateau: relative timing of uplift and magmatism. Geophys. Res. Abstr. 13 (EGU2011-10326).

Bartol, J., Govers, R., Wortel, M.J.R., 2012. Mantle delamination as the cause for the Miocene-Recent evolution of the Central and Eastern Anatolian Plateau. Geophysical Research Abstracts, 14: EGU2012-11778, EGU General Assembly 2012, Vienna, Austria.

Benedetti, L., Tapponnier, P., King, G.C.P., Meyer, B., Manighetti, I., 2000. Growth folding and active thrusting in the Montello region, Veneto, northern Italy, Journal of Geophysical Research 105, B1, 739-766.

Bilgin, T., 1963. Ünye batısında Akçay Pleistosen taraçaları. İstanbul Üniversitesi Coğrafya Enstitüsü Dergisi 7, 13, 37-51.

Bookhagen, B., Strecker, M.R., 2012. Spatiotemporal trends in erosion rates across a pronounced rainfall gradient: Examples from the southern Central Andes, Earth and Planetary Science Letters 327-328, 97-110.

Braucher, R., Merchel, S., Borgomano, J., Bourles, D.L., 2011. Production of cosmogenic radionuclides at great depth: A multi element approach. Earth and Planetary Science Letters 309, 1-9.

Braucher, R., Bourles, D., Merchel, S., Romani, J.V., Fernadez-Mosquera, D., Marti, K., Leanni, L., Chauvet, F., Arnold, M., Aumaitre, G., Keddadouche, K., 2013. Determination of muon attenuation lengths in depth profiles from in situ produced cosmogenic nuclides. Nuclear Instruments and Methods in Physics, Research Section BBeam Interactions with Materials and Atoms 294, 484-490.

Bridgland, D.R., 2000. River terrace systems in north-west Europe: an archive of environmental change, uplift and early human occupation. Quaternary Science Reviews 19, 1293-1303.

Bridgland, D., Westaway, R., 2008. Climatically controlled river terrace staircases: A worldwide Quaternary phenomenon. Geomorphology 98, 285-315.

Bucher, W.H., 1932. "Strath” as a geomorphic term. Science 74, 130-131.

Bull, W.B., 1991. Geomorphic Response to Climatic Change. Oxford University Press, New York, 326 pp.

Burbank, D.W., Anderson, R.S., 2001. Tectonic geomorphology. Blackwell Science, Malden, MA.

Çemen, I., Göncüoğlu, M.C., Dirik, K., 1999. Structural evolution of the Tuzgolu basin in Central Anatolia, Turkey. Journal of Geology 107, 6, 693-706. 
Chmeleff, J., von Blanckenburg, F. Kossert, K., Jakob, D., 2010. Determination of the ${ }^{10} \mathrm{Be}$ half-life by multicollector ICP-MS and liquid scintillation counting: Nuclear Instruments and Methods in Physics Research B 268, 192-199.

Çiner, A., Karabıyıkoğlu, M., Monod, O., Deynoux, M., Tuzcu, S., 2008. Late Cenozoic sedimentary evolution of the Antalya Basin, Southern Turkey. Turkish Journal of Earth Sciences 17, 1-41.

Çiner, A., Desruelles, S., Fouache, E., Koşun, E., Dalongeville, R., 2009. Beachrock formations on the Mediterranean Coast of Turkey: Implications for Holocene sea level changes and tectonics. Geological Bulletin of Turkey 52, 3, 257-296.

Çiner, A., Strecker, M.R., Bertotti, G., 2013. Late Cenozoic Evolution of the Central Anatolia. Turkish Journal of Earth Sciences 22, i-ii.

Cipollari, P., Cosentino, D., Radeff, G., Schildgen, T.F., Faranda, C., Grossi, F., Gliozzi, E., Smedile, A., Gennari, R., Darbas, G., Dudas, F.Ö., Gürbüz, K., Nazik, A., Echtler, H.P., 2013a. Easternmost Mediterranean evidence of the Zanclean flooding event and subsequent surface uplift: Adana Basin, southern Turkey. In: “Geological Development of Anatolia and the Easternmost Mediterranean Region”. Robertson, A.H.F., Parlak, O., Ünlügenç, U.C. (eds.), Geological Society of London Special Publications 372, 473 493. doi:10.1144/SP372.5.

Cipollari, P., Halasova, E., Gürbüz, K., Cosentino, D., 2013b. Middle-Upper Miocene paleogeography of southern Turkey: insights from stratigraphy and calcareous nannofossil biochronology of the Olukpınar and Başyayla sections (Mut-Ermenek Basin). In: "Late Cenozoic Evolution of the Central Anatolia Plateau", Çiner, A., Strecker, M.R., Bertotti, G. (eds.), Turkish Journal of Earth Sciences 22, 820-838.

Clark, M.K., Royden, L.H., 2000. Topographic ooze; building the eastern margin of Tibet by lower crustal flow, Geology 28, 703-706.

Cosentino, D., Schildgen, T.F., Cipollari, P., Faranda, C., Gliozzi, E., Hudáčková, N., Lucifora, S., Strecker, M.R., 2012a. Late Miocene surface uplift of the southern margin of the Central Anatolian Plateau, Central Taurides, Turkey. Geological Society of America Bulletin 124, 133-145. doi.org/10.1130/B30466.1

Cosentino, D., Bertini, A., Cipollari, P., Florindo, F., Gliozzi, E., Grossi, F., Lo Mastro, S., Sprovieri, M., 2012b. Orbitally forced palaeoenvironmental and palaeoclimate changes in the late post-evaporitic Messinian of the central Mediterranean Basin, Geological Society of America Bulletin. doi:10.1130/B30462.1

Çubukcu, E., Şen, E., Aydar, E., 2010. Geochemical characteristics of Quaternary rhyolitic volcanism in Acigöl area, Cappadocia, Türkiye. EGU General Assembly, Vienna, p.14497.

Demir, T., Yeşilnacar, I., Westaway, R., 2004. River terrace sequences in Turkey: sources of evidence for lateral variations in regional uplift. Proceedings of the Geologists' Association 115, 289-311. 
Desilets, D., Zreda, M., Almasi, P.F., Elmore, D., 2006. Determination of cosmogenic Cl-36 in rocks by isotope dilution: innovations, validation and error propagation. Chemical Geology 233, 185-195.

Deynoux, M., Çiner, A., Monod, O., Karabıyıkoğlu, M., Manatschal, G., Tuzcu, S., 2005. Facies architecture and depositional evolution of alluvial fan to fan-delta complexes in the tectonically active Miocene Köprüçay Basin, Isparta Angle, Turkey. In: "Cenozoic Sedimentary Basins of South Central Turkey." Kelling, G., Robertson, A.H.F., van Buchem, F. (eds.), Sedimentary Geology 173, 1-4, 315-343. doi:10.1016/j.sedgeo.2003.12.013.

Doğan, U., 2010. Fluvial response to climate change during and after the Last Glacial Maximum in Central Anatolia, Turkey, Quaternary International 222, 221-229.

Doğan, U., 2011. Climate-controlled river terrace formation in the Kizılırmak Valley, Cappadocia section, Turkey: Inferred from Ar-Ar dating of Quaternary basalts and terraces stratigraphy. Geomorphology 126, 66-81.

Dunai, T.J., 2012. Cosmogenic Nuclides Principles, Concepts and Applications in the Earth Surface Sciences. Cambridge University Press, Cambridge, 187p.

Elmore, D., Ma, X., Miller, T., Mueller, K., Perry, M., Rickey, F., Sharma, P., Simms, P., Lipschutz, M., Vogt, S., 1997. Status and plans for the PRIME Lab AMS facility. Nuclear Instruments and Methods in Physics Research Section B-Beam Interactions with Materials and Atoms 123, 69-72.

Erlanger, E.D., Granger, D.E., Gibbon, R.J., 2012. Rock uplift rates in South Africa from isochron burial dating of fluvial and marine terraces. Geology 40, 1019-1022. 10.1130.G33172.1.

Faccenna, C., Becker, T.W., 2010. Shaping mobile belts by small-scale convection. Nature 465 (7298), 602-605.

Faccenna, C., Becker, T.W., Auer, L., Billi, A., Boschi, L., Brun, J.-P., Capitanio, F.A., Funiciello, F., Horvàth, F., Jolivet, L., Piromallo, C., Royden, L., Rossetti, F., Serpelloni, E., 2014. Mantle dynamics in the Mediterranean. Review of Geophysics 52, doi:10.1002/2013RG000444.

Faranda, C., Gliozzi, E., Cipollari, P., Grossi, F., Darbaş, G., Gürbüz, K., Nazik, A., Gennari, R., Cosentino, D., 2013. Messinian paleoenvironmental changes in the easternmost Mediterranean Basin (Adana Basin, Southern Turkey). In: "Late Cenozoic Evolution of the Central Anatolia Plateau", Çiner, A., Strecker, M.R., Bertotti, G. (eds.), Turkish Journal of Earth Sciences 22, 839-863.

Fernández-Blanco, D., Bertotti, G., Cassola, T., Willett, S., 2012. Neogene vertical tectonics of the south margin of the Central Anatolia plateau in relation to Cyprus Arc subduction. American Geophysical Union 2012 Fall Meeting, San Francisco, CA, T33B-2663.

Fernández-Blanco, D., Bertotti, G., Çiner, A., 2013. Cenozoic tectonics of the Tuz Gölü Basin (Central Anatolia Plateau, Turkey. In: "Late Cenozoic Evolution of the Central Anatolia 
Plateau", Çiner, A., Strecker, M.R., Bertotti, G. (eds.), Turkish Journal of Earth Sciences 22, 715-738.

Garcia-Castellanos, D., 2006. The role of climate during high plateau formation. Insights from numerical modeling. Earth and Planetary Science Letters 257, 372-390.

Garzione, C.N., Molnar, P., Libarkin, J.C., MacFadden, B., 2006. Rapid Late Miocene rise of the Bolivian Altiplano: evidence for removal of mantle lithosphere. Earth and Planetary Science Letters 241, 543-56.

Gautier, P., Brun, J.-P., Moriceau, R., Sokoutis, D., Martinod, J., Jolivet, L., 1999. Timing, kinematics and cause of Aegean extension: a scenario based on a comparisoin with simple analogue experiments. Tectonophysics 315, 1-4, 31-72.

Genç, Y., Yürür, T., 2010. Coeval extension and compression in Late Mesozoic and Recent thin-skinned extensional tectonics in central Anatolia, Turkey. Journal of Structural Geology 32, 623-640.

Gibbard, P.L., Lewin, J., 2009. River incision and terrace formation in the Late Cenozoic of Europe. Tectonophysics 474, 41-55.

Göğüş, O.H., Pysklywec, R.N., 2008. Mantle lithosphere delamination driving plateau uplift and synconvergent extension in eastern Anatolia. Geology 36, 723-726.

Görendağl1, N., 2011. Kızılırmak sekilerinin oluşumunda iklim ve tektoniğin rolü, Avanos. Ankara Ü. Coğrafi Bilimleri Dergisi 9, (2), 221.238.

Görür, N., Oktay, F., Seymen, İ., Şengör, A.M.C., 1984. Palaeotectonic evolution of the Tuzgölü basin complex, Central Turkey: sedimentary record of a Neo-Tethyan closure. Geological Society of London Special Publications 17, 467-482.

Gosse, J.C., Phillips, F.M., 2001. Terrestrial in situ cosmogenic nuclides: theory and application: Quaternary Science Reviews 20, 1475-1560.

Granger, D.E., Kirchner, J.W., Finkel, R.C., 1997. Quaternary downcutting rate of the New River, Virginia, measured from differential decay of cosmogenic Al-26 and Be-10 in cave-deposited alluvium. Geology 25, 107-110.

Granger, D.E., Muzikar, P.F., 2001. Dating sediment burial with in situ-produced cosmogenic nuclides: theory, techniques, and limitations. Earth and Planetary Science Letters 188, 269-281.

Granger, D.E., 2006. A review of burial dating methods using 26Al and 10Be, Geological Society of America Special Papers 415, 1-16.

Haghipour, N., Burg, J.P., Kober, F., Zeilinger, G., Ivy-Ochs, S., Kubik, P.W., Faridi, M., 2012. Rate of crustal shortening and non-Coulomb behaviour of an active accretionary wedge: The folded fluvial terraces in Makran (SE, Iran). Earth And Planetary Science Letters 355, 187-198.

Hancock, G.S., Anderson, R.S., Chadwick, O.A., Finkel, R.C., 1999. Dating of fluvial terraces using ${ }^{10} \mathrm{Be}$ and ${ }^{26} \mathrm{Al}$ profiles, Wind River, Wyoming. Geomorphology 27, $41-$ 60. 
Hancock, G.S., Anderson, R.S., 2002. Numerical modeling of fluvial strath-terrace formation in response to oscillating climate, Geological Society of America Bulletin 114, 9, 1131 1142 .

Heisinger, B., Lal, D., Jull, A.J.T., Kubik, P., Ivy-Ochs, S., Neumaier, S., Knie, K., Lazarev, V., Nolte, E., 2002a. Production of selected cosmogenic radionuclides by muons: 1. Fast muons, Earth and Planetary Science Letters 200, 345-355.

Heisinger, B., Lal, D., Jull, A.J.T., Kubik, P., Ivy-Ochs, S., Knie, K., Nolte, E., 2002b. Production of selected cosmogenic radionuclides by muons: 2. Capture of negative muons, Earth and Planetary Science Letters 200, 357-369.

Hetzel, R., Niedermann, S., Tao, M., Kubik, P.W., Ivy-Ochs, S., Gao, B., Strecker, M.R., 2002. Low slip rates and long-term preservation of geomorphic features in Central Asia. Nature 417, 428-432.

Hidy, A.J., Gosse, J.C., Pederson, J.L., Mattern, J.P., Finkel R.C., 2010. A geologically constrained Monte Carlo approach to modeling exposure ages from profiles of cosmogenic nuclides: An example from Lees Ferry, Arizona, Geochemistry, Geophysics, Geosystems 11.

Ilgar, A., Wojciech N., Hakyemez, A., Karakuş, E., 2013. Messinian forced regressions in the Adana Basin: a near-coincidence of tectonic and eustatic forcing. In: "Late Cenozoic Evolution of the Central Anatolia Plateau”, Çiner, A., Strecker, M.R., Bertotti, G. (eds.), Turkish Journal of Earth Sciences 22, 864-889.

Innocenti, F., Mazzuoli, R., Pasquaré, G., Radicati di Brozolo, F., Villari, L., 1975. The Neogene calc-alkaline volcanism of central Anatolia: geochronological data on KayseriNigde area. Geological Magazine 112, 349-360.

Ivy-Ochs, S., Synal, H.A., Roth, C., Schaller, M., 2004. Initial results from isotope dilution for $\mathrm{Cl}$ and $\mathrm{Cl}-36$ measurements at the PSI/ETH Zurich AMS facility. Nuclear Instruments and Methods in Physics Research Section B-Beam Interactions with Materials and Atoms 223-24, 623-627.

Ivy-Ochs, S., Dühnforth, M., Densmore, A.L., Alfimov, V., 2013. Dating Fan Deposits with Cosmogenic Nuclides. Advances in Global Change Research. In: Dating Torrential Processes on Fans and Cones. Methods and Their Application for Hazard and Risk Assessment. Schneuwly-Bollschweiler, M., Stoffel, M., Rudolf-Miklau, F., (eds.), 47, 243-263. ISBN: 978-94-007-4335-9

Karabıyıkoğlu, M., Çiner, A., Monod, O., Deynoux, M., Tuzcu, S., Örçen, S., 2000. Tectonosedimentary evolution of the Miocene Manavgat Basin, Western Taurids, Turkey. In: "Tectonics and Magmatism in Turkey and the Surrounding Area", Bozkurt, E. Winchester, J.A., Piper, J.A.D. (eds.), Geological Society of London Special Publication 173, 271-294. DOI: 10.1144/GSL.SP.2000.173.01.14.

Karabıyıkoğlu, M., Tuzcu, S., Çiner, A., Deynoux, M, Örçen., S., Hakyemez, A., 2005. Facies and environmental setting of the Miocene coral reefs in the Late-Orogenic fill of the Antalya Basin, Western Taurids, Turkey. In: "Cenozoic Sedimentary Basins of South Central Turkey.” Kelling, G., Robertson, A.H.F., van Buchem, F. (eds.), Sedimentary 
Geology 173, 1-4, 345-371.

Kay, R.W., Kay, S.M., 1993. Delamination and delamination magmatism. Tectonophysics 219 177-189.

Kohl, C.P., Nishiizumi, K., 1992. Chemical Isolation of Quartz for Measurement of InsituProduced Cosmogenic Nuclides. Geochimica et Cosmochimica Acta 56, 3583-3587.

Korschinek, G., Bergmaier, A., Faestermann, T., Gerstmann, U.C., Knie, K., Rugel, G., Wallner, A., Dillmann, I., Dollinger, G., von Gostomski, C.L., Kossert, K., Maiti, M., Poutivtsev, M., Remmert, A., 2010. A new value for the half-life of Be-10 by HeavyIon Elastic Recoil Detection and liquid scintillation counting. Nuclear Instruments and Methods in Physics Research Section B-Beam Interactions with Materials and Atoms 268, 187-191.

Kubik, P.W., Christl, M., 2010. 10Be and 26Al measurements at the Zurich 6 MV Tandem AMS facility. Nuclear Instruments and Methods in Physics Research B 268, 880-883.

Kürçer, A., Gökten, E., 2012. Paleoseismological three dimensional virtual photography method; a case study: Bağlarkayas1-2010 trench, Tuz Gölü Fault Zone, Central Anatolia, Turkey. InTech (Tectonics-Recent Advances) 201-228. doi:10.5772/48194.

Lal, D., 1991. Cosmic ray labeling of erosion surfaces: in situ nuclide production rates and erosion models: Earth and Planetary Science Letters 104, 424-439.

Lavé J., Avouac, J.P., 2000. Active folding of fluvial terraces across the Siwalik Hills (Himalaya of central Nepal, Journal Geophysical Research 105, 5735-5770.

Lavé J., Avouac, J.P., 2001. Fluvial incision and tectonic uplift across the Himalayas of Central Nepal, Journal Geophysical Research 106, 26,561-26,592.

Le Pennec J.-L., Temel, A., Froger, J.L, Şen, Ş., Gourgaud, A., Bourdier, J.-L., 2005. Stratigraphy and age of the Cappadocia ignimbrites, Turkey: Reconciling field constraints with paleontologic, radiochronologic, geochemical and paleomagnetic data. Journal of Volcanology and Geothermal Research 141 (1-2), 45-64.

Liu, B.L., Phillips, F.M., Fabrykamartin, J.T., Fowler, M.M., Stone, W.D., 1994. Cosmogenic $36 \mathrm{Cl}$ accumulation in unstable landforms, 1. Effects of the thermal neutron distribution. Water Resources Research 30, 3115-3125.

Maddy, D., 1997. Uplift driven valley incision and river terrace formation in southern England. Journal of Quaternary Science 12, 539-545.

Maddy, D., Bridgland, D., Westaway, R., 2001. Uplift driven valley incision and climatecontrolled river terrace development in the Thames Valley, UK. Quaternary International 79, 23-36.

Maddy, D., Demir, T., Bridgland, D.R., Veldkamp, A., Stemerdink, C., van der Schriek, T., Schreve, D., 2007. The Pliocene initiation and Early Pleistocene volcanic disruption of the palaeo-Gediz fluvial system, Western Turkey: Quaternary Science Reviews, 26, 2864-2882. 
Matmon, A., Nichols, K., Finkel, R., 2006. Isotopic insights into smoothening of abandoned fan surfaces, Southern California. Quaternary Research 66, 109-118.

Mazzini, I., Hudackova, N., Joniak, P., Kovacova, M., Mikes, T., Mulch, A., Rojay, B.F., Lucifora, S., Esu, D., Ingeborg, S.M., 2013. Paleoenvironmental and chronological constraints on the Tuğlu Formation (Çankırı Basin, Central Anatolia, Turkey). In: "Late Cenozoic Evolution of the Central Anatolia Plateau", Çiner, A., Strecker, M.R., Bertotti, G. (eds.), Turkish Journal of Earth Sciences 22, 747-777. http://dx.doi.org/10.3906/yer1207-10.

McKenzie, D.P., 1972. Active tectonics of the Mediterranean region. Geophysical Journal of Royal Astronomical Society 30, 2, 109-185.

Merritts, D.J., Vincent, K.R., Wohl, E.E., 1994. Long river profiles, tectonism, and eustasy: A guide to interpreting fluvial terraces: Journal of Geophysical Research 99, 14031-14050, doi:10.1029/94JB00857.

Molnar, P., England, P., Martinod, J., 1993. Mantle dynamics, uplift of the Tibetan Plateau, and the Indian monsoon. Reviews of Geophysics 31, 357-396.

Monod, O., Kuzucuoğlu, C., Okay, A., 2006. A Miocene paleovalley network in the western Taurus (Turkey). Turkish Journal of Earth Sciences 15, 1-23.

Montero Lopez, M.C., Hongn, F.D., Strecker, M.R., Marrett, R., Seggiaro, R., Sudo, M., 2010. Late Miocene-early Pliocene onset of N-S extension along the southern margin of the central Andean Puna Plateau: Evidence from magmatic, geochronological and structural observations, Tectonophysics 494, 48-63.

Nishiizumi, K., 2004. Preparation of Al-26 AMS standards. Nuclear Instruments and Methods in Physics Research Section B-Beam Interactions with Materials and Atoms 223, 388.

Norris, T.L., Gancarz, A.J., Rokop, D.J., Thomas, K.W., 1983. Half-Life of Al-26. Journal of Geophyscal Research 88, B331-B333.

Özsayın, E., Çiner, A., Dirik, K., Rojay, B, Fernández-Blanco, D., Melnick, D., Garcin, Y., Bertotti, G., Strecker, M., Schildgen, T., Sudo, M., 2013. Plio-Quaternary Extensional Tectonics of the Central Anatolian Plateau: A case study from the Tuz Gölü Basin, Turkey. In: "Late Cenozoic Evolution of the Central Anatolia Plateau", Çiner, A., Strecker, M.R., Bertotti, G. (eds.), Turkish Journal of Earth Sciences 22, 691-714.

Pasquaré, G., 1968. Geology of the Cenezoic volcanic area of Central Anatolia. Atti Accad. Naz. Lincei 9, 53-204.

Pazzaglia, F.J., Brandon, M.T., 2001. A fluvial record of long-term steady-state uplift and erosion across the Cascadia Forearc High, Western Washington State, American Journal of Science 301, 4-5, 385-431.

Phillips, F.M., Stone, W.D., Fabryka-Martin, J.T., 2001. An improved approach to calculating low-energy cosmic-ray neutron fluxes near the land/atmosphere interface: Chemical Geology 175, 689-701.

Pourteau, A., Candan, O., Oberhänsli, R., 2010. High-pressure metasediments in central Turkey: Constraints on the Neotethyan closure history. Tectonics 29, TC5004. 
Raymo, M.E., 1992. Global climate change: a three million year perspective. In: Kukla, G., Went, E. (eds.), Start of a Glacial, Proceedings of the Mallorca NATO ARW, NATO ASI Series I, 3, Springer-Verlag, Heidelberg, 207-223.

Repka, J., Anderson R.S., Finkel, R.C., 1997. Cosmogenic dating of fluvial terraces, Fremont River, Utah. Earth and Planetary Science Letters 152, 59-73.

Rixhon, G., Braucher, R., Bourlès, D., Siame, L., Bovy, B., Demoulin, A., 2011. Quaternary river incision in NE Ardennes (Belgium)-Insights from 10Be/26Al dating of river terraces. Quaternary Geochronology 6, 273-284.

Robertson, A.H.F., Dixon, J.E., 1984. Introduction: aspects of the geological evolution of the Eastern Mediterranean. In: Dixon, J.E., Robertson, A.H.F. (eds.). The Geological Evolution of the Eastern Mediterranean. Geological Society of London Special Publications 17, 1-74.

Robertson, A.H.F., 1998. Tectonic significance of the Eratosthenes Seamount: a continental fragment in the process of collision with a subduction zone in the eastern Mediterranean (Ocean Drilling Program Leg 160). Tectonophysics 298, 63-82.

Sarıkaya, M.A., Zreda, M., Çiner, A., Zweck, C., 2008. Cold and wet Last Glacial Maximum on Mount Sandiras, SW Turkey, inferred from cosmogenic dating and glacier modeling. Quaternary Science Reviews 27, 7-8, 769-780.

Sarıkaya, M. A., Zreda, M., Çiner, A., 2009. Glaciations and paleoclimate of Mount Erciyes, central Turkey, since the Last Glacial Maximum, inferred from ${ }^{36} \mathrm{Cl}$ cosmogenic dating and glacier modeling. Quaternary Science Reviews 28, 23-24, 2326-2341.

Sarıkaya, M.A., Çiner, A., Zreda, M., 2011. Quaternary Glaciations of Turkey. In: "Quaternary Glaciations-extent and chronology; a closer look", Ehlers, J., Gibbard, P.L., Hughes, P.D. (eds.): Elsevier Publications, Developments in Quaternary Science 15, Amsterdam, The Netherlands, 393-403. doi:10.1016/B978-0-444-53447-7.00030-1.

Sarıkaya, M.A., Çiner, A., Haybat, H., Zreda, M., 2014. An early advance of glaciers on Mount Akdağ, SW Turkey, before the global Last Glacial Maximum; insights from cosmogenic nuclides and glacier modeling, Quaternary Science Reviews 88, 96-109.

Schattner, U., 2010. What triggered the early-to-mid Pleistocene tectonic transition across the entire eastern Mediterranean? Earth and Planetary Science Letters 289, 539-548.

Schemmel, F., Mikes, T., Rojay, B., Mulch, A., 2013. The impact of topography on isotopes in precipitation across the Central Anatolian Plateau (Turkey). American Journal of Science 313, 2, 61-80.

Schildgen, T.F., Cosentino, D., Bookhagen, B., Niedermann, S., Yıldırım, C., Echtler, H.P., Wittmann, H., Strecker, M.R., 2012a. Multi-phase uplift of the southern margin of the Central Anatolian plateau: A record of tectonic and upper mantle processes. Earth and Planetary Science Letters 317-318, 85-95.

Schildgen, T.F., Cosentino, D., Caruso, A., Buchwaldt, R., Yıldırım, C., Rojay, B., Bowring, S.A., Echtler, H., Strecker, M.R., 2012b. Surface expression of Eastern Mediterranean slab dynamics: Neogene topographic and structural evolution of the SW margin of the 
Schildgen, T.F., Yıldırım, C., Cosentino, D., Strecker, M.R., 2013. Linking slab break-off, Hellenic trench retreat, and uplift of the Central and Eastern Anatolian plateaus, Earth Science Reviews doi:10.1016/j.earscirev.2013.11.006

Schildgen, T.F., Yıldırım, C., Cosentino, D., Strecker, M.R., 2014. Linking slab break-off, Hellenic trench retreat, and uplift of the Central and Eastern Anatolian plateaus. EarthScience Reviews 128, 147-168.

Schmitt, A.K., Danisik, M., Evans, N.J., Siebel, W., Kiemele, E., Aydın, F., Harvey, J.C., 2011. Acigöl rhyolite field, Central Anatolia (part 1): high-resolution dating of eruption episodes and zircon growth rates. Contrib. Mineral. Petrol. 162, 1215-1231. doi:10.1007/s00410-011-0648-x.

Schneider, B., Kuiper, K., Postma, O., Wijbrans, J., 2009. 40Ar/39Ar geochronology using a quadrupole mass spectrometer. Quaternary Geochronolgy 4, 508-516.

Şen, E., Kürkçüoğlu, B., Aydar, E., Gourgaud, A., Vincent, P.M., 2003. Volcanological evolution of Mount Erciyes stratovolcano and origin of the Valibaba Tepe ignimbrite. Journal of Volcanology and Geothermal Research 125, 225-246.

Şengör, A.M.C., Yılmaz, Y., 1981. Tethyan evolution of Turkey: a plate tectonic approach. Tectonophysics 75, 181-241.

Şengör, A.M.C., Görür, N., Şaroğlu, F., 1985. Strike-slip faulting and basin related formation in zones of tectonic escape: Turkey as a case study. In: Strike-Slip Deformation, Basin Formation and Sedimentation. Biddle, K.T., Christie-Blick, N. (eds.). Society of Economic Paleontologists and Mineralogists Special Publication 37, 227-440.

Şengör, A.M.C., Özeren, S., Genç, T., Zor, E., 2003. East Anatolian high plateau as a mantlesupported, North-south shortened domal structure, Geophysical Resarch Letters 30, 24, 8045, doi:10.1029/2003GL017858

Şengör, A.M.C., Özeren, S., Keskin, M., Sakınç, M. Özbakır, A.D., Kayan, İ., 2008. Eastern Turkish high plateau as a small Turkic-type orogen: Implications for post-collisional crust-forming processes in Turkic-type orogens, Earth-Science Reviews 90, 1-48.

Sims, K.W.W., Ackert, R.P., Ramos, F.C., Sohn, R.A., Murrell, M.T., De Paolo, D.J., 2007. Determining eruption ages and erosion rates of Quaternary basaltic volcanism from combined U-series disequilibria and cosmogenic exposure ages. Geology 35, 471-474.

Stone, J.O., 2000. Air pressure and cosmogenic isotope production. Journal of Geophysical Research-Solid Earth 105, 23753-23759.

Stone, J.O., Allan, G.L., Fifield, L.K., Cresswell, R.G., 1996. Cosmogenic chlorine-36 from calcium spallation. Geochimica et Cosmochimica Acta 60, 679-692.

Stone, J.O., Evans, J.M., Fifield, L.K., Allan, G.L., Cresswell, R.G., 1998. Cosmogenic chlorine-36 production in calcite by muons. Geochimica et Cosmochimica Acta 62, 433-454. 
Synal, H.A., Bonani, G., Dobeli, M., Ender, R.M., Gartenmann, P., Kubik, P.W., Schnabel, C., Suter, M., 1997. Status report of the PSI/ETH AMS facility. Nuclear Instruments and Methods in Physics Research Section B-Beam Interactions with Materials and Atoms 123, 62-68.

Temel, A., Gündoğdu, M.N., Gourgaud, A., Le Pennec, J-L., 1998. Ignimbrites of Cappadocia (Central Anatolia, Turkey): petrology and geochemistry. Journal of Volcanology and Geothermal Research 85, 55-67.

Toprak, V., 1998. Vent distrubiton and its relation to regional tectonics, Cappadocian Volcanics, Turkey. Journal of Volcanology and Geothermal Research 85, 55-67.

Vandenberghe, J., 2003. Forcing of fluvial system development: An evolution of ideas, Quaternary Science Reviews 22, 20, 2053-2060.

Wang, C. Dai, J., Zhao, X., Li, Y., Graham, S.A., He, D., Ran, B., Meng, J., 2014. Outwardgrowth of the Tibetan Plateau during the Cenozoic: A review. Tectonophysics 621, 143.

Wegmann, K. W., Pazzaglia, F.J., 2009. Late Quaternary fluvial terraces of the Romagna and Marche Apennines, Italy: Climatic, lithologic, and tectonic controls on terrace genesis in an active orogen, Quaternary Science Reviews 28, 1-2, 137-165.

Westaway, R., Pringle, M., Yurtmen, S., Demir, T., Bridgland, D., Rowbotham, G., Maddy, D., 2004. Pliocene and Quaternary regional uplift in western Turkey: The Gediz river terrace staircase and the volcanism at Kula. Tectonophysics 391, 121-169.

Westaway, R., Guillou, H., Yurtmen, S., Beck, A., Bridgland, D., Demir, T., Scaillet, S., Rowbotham, G., 2006. Late Cenezoic uplift of western Turkey: Improved dating of the Kula Quaternary volcanic field and numerical modelling of the Gediz River terrace staircase. Global and Planetary Change 51, 131-171.

Yıldırım, C., Schildgen, T.F. Echtler, H. Melnick, D., Strecker, M.R., 2011. Late Neogene and active orogenic uplift in the Central Pontides associated with the North Anatolian Fault; implications for the northern margin of the Central Anatolian Plateau, Turkey: Tectonics 30, TC5005. doi:10.1029/2010TC002756.

Yıldırım, C., Melnick, D., Ballato, P., Schildgen, T., Echtler, H., Erginal, E., Kiyak, N.G., Strecker, M.R., 2013a. Differential uplift along the northern margin of the Central Anatolian Plateau: inferences from marine terraces. Quaternary Science Reviews 81, $12-28$.

Yıldırım, C., Schildgen, T., Echtler, H., Melnick, D., Strecker, M.R., Bookhagen, B., Çiner, A., Niederman, S., Merchel, S., Martschini, M., Steier, P., Strecker, M.R., 2013b. Tectonic implications of fluvial incision and pediment deformation at the northern margin of the Central Anatolian Plateau based on multiple cosmogenic nuclides. Tectonics 32, 1-14. doi:10.1002/tect.20066.

Zreda, M.G., Phillips, F.M. Elmore, D. Kubik, P.W. Sharma, P., Dorn, R.I., 1991. Cosmogenic chlorine-36 production rates in terrestrial rocks. Earth and Planetary Science Letters 105, 94-109. 
Zreda, M., Çiner, A., Sarıkaya, M.A., Zweck, C., Bayarı, S., 2011. Remarkably extensive Early Holocene glaciation in Aladağlar, Central Turkey, Geology 39, 11, 1051-1054. doi:10.1130/G32097.1.

\section{Figures and Tables}

Fig. 1. a) Location and b) Digital Elevation Model of the study area (modified from Atabey 1989). TGF: Tuz Gölü Fault. Large white box indicates swath profile in Fig. 8.

Fig. 2. Geomorphologic map of the study area (UTM zone 36N); a) Gülşehir section (modified from Doğan, 2011), b) Avanos section (modified from Görendağl1, 2011). White dashed line indicates topographical profile in Fig. 7. TCN: Terrestrial Cosmogenic Nuclide.

Fig. 3. North-south oriented cross-sections of the studied terraces (modified from Doğan 2011). See Fig. 2 for cross-section locations.

Fig. 4. Field pictures of the terraces (white stars indicate sampling sites and sample numbers): a) T6 at Sarıhıdır gravel quarry; b) cross-bedded conglomerates and overlying floodplain finegrained sediments; c) quartz pebble samples (TCAP-1 to 3) collected from T6 for cosmogenic dating; d) T6 surface near Yüksekli village covered by cm size quartz pebbles; e) T8 and T9 near Avanos; f) T9 along Gülşehir-Avanos road; g) calcareous pebble samples collected for cosmogenic dating; h) T12 to NW of Gülşehir showing sampled conglomerates overlain by thick floodplain fine-grained sediments; i) close up view of T12 conglomerates and sample location; j) T12 near Gürüzlük Hill and fine-grained floodplain sediments and Tuzköy Basalt Plateau ( $\beta 3$ ) basalts; k) T13 with fine-grained quartz pebbles and Karnıarık Hill Basalt ( $\beta 4)$ on top; 1) detail from the sampling site.

Fig. 5: a) corrected isochron age for samples TCAP-1; b) TCAP-3 ${ }^{10} \mathrm{Be}$ vs ${ }^{26} \mathrm{Al}$; c) corrected isochron age for samples TCAP-3; d) corrected isochron age for samples TCAP-4; e) isochron age for samples TCAP-5.

Fig. 6: TCAP average incision rate $(51 \pm 1 \mathrm{~m} / \mathrm{Ma})$.

Fig. 7: Schematic section showing the relationship between the Evren Ridge Basalt $(\beta 1)$ and the modern valley floor. See Fig. 2 for location of the profile.

Fig. 8: Swath profile of the CAP. Dashed line indicates the mean elevation. Vertical exaggeration is $\mathrm{x} 100$. See Fig. 1 for the swath section.

Table 1: Sample descriptions from the Kizilirmak terraces.

Table 2: ${ }^{10} \mathrm{Be}$ and ${ }^{26} \mathrm{Al}$ results of samples from the Kizilirmak terraces.

Table 3: Cosmogenic nuclide ages for the Kizılırmak terraces.

Table 4: Incision rates of the Kizilırmak based on dated terraces.

Appendix 1: ${ }^{36} \mathrm{Cl}$ data from sample AVA1-CN2. 
Table 1. Sample descriptions from the Kızılırmak River terraces.

\begin{tabular}{|c|c|c|c|c|c|c|}
\hline $\begin{array}{l}{ }^{\mathrm{a}} \text { Terrace } \\
\text { Number }\end{array}$ & $\begin{array}{l}\text { Sample } \\
\text { Name }\end{array}$ & $\begin{array}{c}\text { Sample } \\
\text { depth } \\
(\mathrm{cm})\end{array}$ & Sample Type & $\begin{array}{l}\text { Latitude, } \\
{ }^{\circ} \mathrm{N} \text { (DD.DD) }\end{array}$ & $\begin{array}{l}\text { Longitude, } \\
{ }^{\circ} E \text { (DD.DD) }\end{array}$ & $\begin{array}{l}\text { Altitude } \\
\text { (m a.s.I.) }\end{array}$ \\
\hline T6 (+100 m) & TCAP-1 & 1000 & pebbles & 38.7201 & 34.9267 & 1025 \\
\hline South of the river & TCAP-1A & & single clast & & & \\
\hline Sarıhıdır Gravel Pit & TCAP-1B & & single clast & & & \\
\hline \multirow[t]{4}{*}{ (Fig. 2b) } & TCAP-1C & & single clast & & & \\
\hline & TCAP-1(2) & & pebbles & & & \\
\hline & TCAP-1(3) & & pebbles & & & \\
\hline & TCAP-1(4) & & pebbles & & & \\
\hline T6 (+100 m) & TCAP-6 & surface & pebbles & 38.8044 & 34.5284 & 980 \\
\hline \multicolumn{7}{|l|}{$\begin{array}{l}\text { North of the river } \\
\text { (Fig. 2a) }\end{array}$} \\
\hline $\mathrm{T}-8(+75 \mathrm{~m})$ & TCAP-5A & 350 & single clast & 38.7073 & 34.8737 & 992 \\
\hline South of the river & TCAP-5B & & pebbles & & & \\
\hline Karaseki terrace & TCAP-5C & & pebbles & & & \\
\hline \multirow[t]{2}{*}{ (Fig. 2b) } & TCAP-5D & & pebbles & & & \\
\hline & TCAP-5E & & pebbles & & & \\
\hline T9 (+55 m) & AVA1-CN2 & surface & pebbles & 38.7500 & 34.770 & 930 \\
\hline \multicolumn{7}{|l|}{$\begin{array}{l}\text { North of the river } \\
\text { (Fig. 2b) }\end{array}$} \\
\hline $\mathrm{T} 12(+20 \mathrm{~m})$ & TCAP-2 & 1000 & pebbles & 38.7692 & 34.5924 & 930 \\
\hline \multicolumn{7}{|l|}{$\begin{array}{c}\text { North of the river } \\
\text { (Figure 2a) }\end{array}$} \\
\hline $\mathrm{T} 12(+31 \mathrm{~m})$ & TCAP-4A & 500 & single clast & 38.7833 & 34.5253 & 914 \\
\hline \multirow{5}{*}{$\begin{array}{l}\text { South of the river } \\
\text { (Fig. 2a) }\end{array}$} & TCAP-4B & & single clast & & & \\
\hline & TCAP-4C & & single clast & & & \\
\hline & TCAP-4D & & single clast & & & \\
\hline & TCAP-4E & & single clast & & & \\
\hline & TCAP-4F & & single clast & & & \\
\hline \multirow{9}{*}{$\begin{array}{c}\text { T13 }(+13) \\
\text { South of the river } \\
\text { (Fig. 2a) }\end{array}$} & TCAP-3A & $10^{\mathrm{b}}$ & pebbles & 38.7737 & 34.5557 & 916 \\
\hline & TCAP-3B & $30^{b}$ & pebbles & & & \\
\hline & TCAP-3B2 & $40^{b}$ & pebbles & & & \\
\hline & TCAP-3C & $50^{b}$ & pebbles & & & \\
\hline & TCAP-3D & $70^{b}$ & pebbles & & & \\
\hline & TCAP-3E & $90^{b}$ & pebbles & & & \\
\hline & TCAP-3F & $120^{b}$ & pebbles & & & \\
\hline & TCAP-3G & $190^{b}$ & pebbles & & & \\
\hline & TCAP-3H & $250^{b}$ & pebbles & & & \\
\hline
\end{tabular}

${ }^{\mathrm{a}}$ Terrace numbers from Doğan (2011)

${ }^{b}$ Depth from the bottom of Karnıyarık Basalts 
Table 2. ${ }^{10} \mathrm{Be}$ and ${ }^{26} \mathrm{Al}$ results of samples from the Kizlırmak River terraces in Turkey

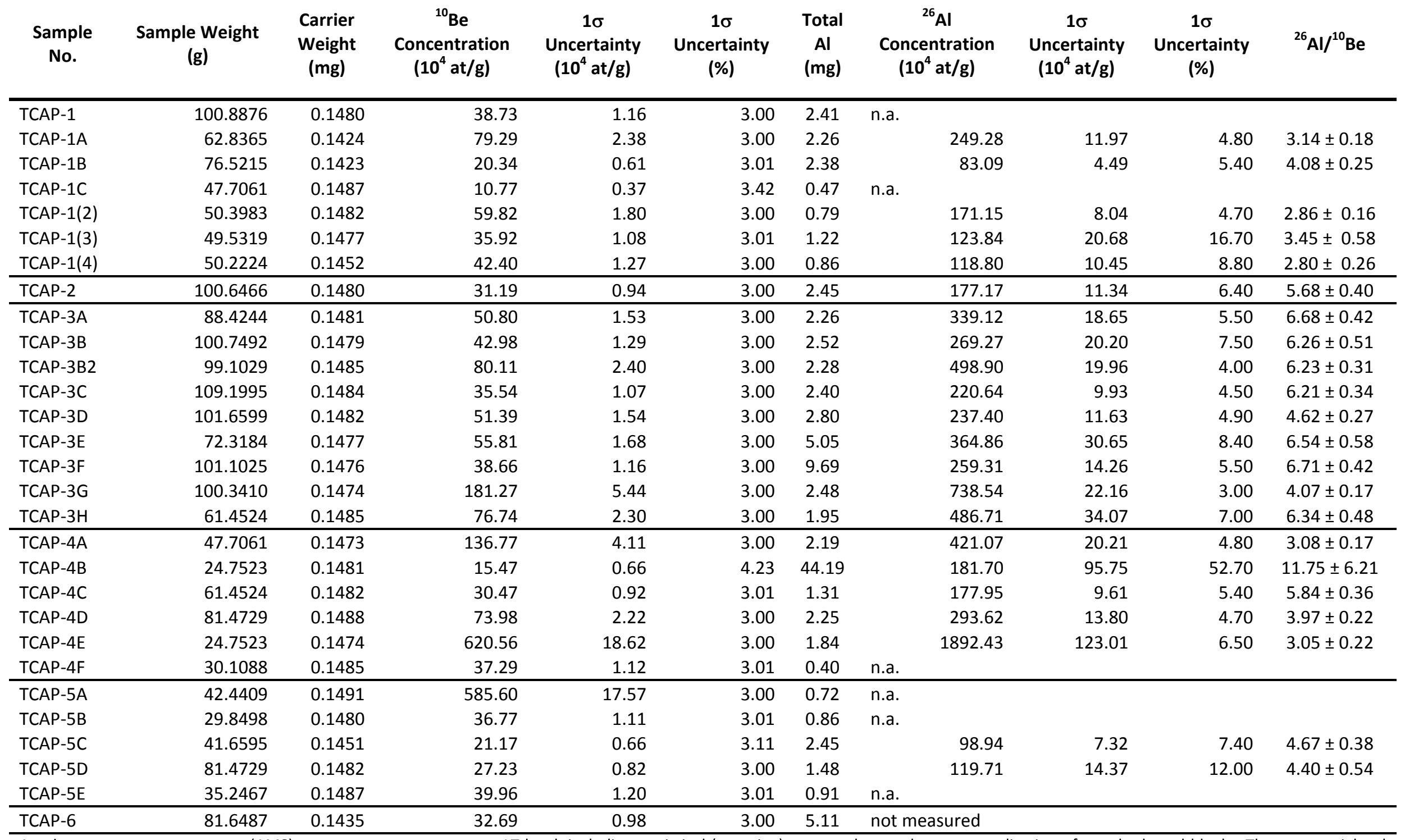

Accelerator mass spectrometry (AMS) measurement errors are at 19 level, including statistical (counting) error and error due to normalization of standards and blanks. The error weighted average ${ }^{10} \mathrm{Be} /{ }^{9} \mathrm{Be}$ full-process blank ratio is $(3.13 \pm 0.36) \times 10^{-15} \cdot{ }^{26} \mathrm{Al} /{ }^{10} \mathrm{Be}$ ratios are calculated with the CRONUS-Earth exposure age calculator and are referenced to 07KNSTD (http://

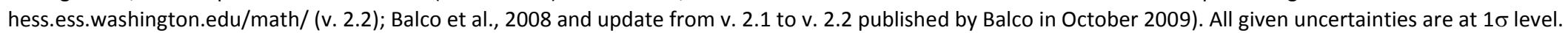


Table 3. Cosmogenic nuclide ages for the Kızılırmak terraces

\begin{tabular}{|c|c|c|c|c|c|c|}
\hline $\begin{array}{l}\text { Terrace } \\
\text { Number }\end{array}$ & $\begin{array}{l}\text { Sample } \\
\text { Name }\end{array}$ & Type of dating & $\begin{array}{c}{ }^{10} \mathrm{Be} \\
\text { linearization } \\
\text { factor }\end{array}$ & $\begin{array}{c}\text { Inherited }{ }^{10} \mathrm{Be} \\
\text { Concentration } \\
\left(10^{3} \mathrm{at} / \mathrm{g}\right)\end{array}$ & Remark & $\begin{array}{l}\text { Age } \\
\text { (ka) }\end{array}$ \\
\hline \multirow[t]{5}{*}{ T-6 } & TCAP-1A & Isochron burial dating & 0.9164 & 34.89 & & \multirow{5}{*}{$1890 \pm 100$} \\
\hline & TCAP-1B & & 0.9884 & 4.48 & & \\
\hline & TCAP-1(2) & & 0.9390 & 24.85 & & \\
\hline & TCAP-1(3) & & 0.9683 & 12.52 & & \\
\hline & TCAP-1(4) & & 0.9602 & 15.86 & & \\
\hline $\mathrm{T}-6$ & TCAP-6 & $\begin{array}{l}\text { Surface exposure dating } \\
\qquad\left({ }^{10} \mathrm{Be}-{ }^{26} \mathrm{Al}\right)\end{array}$ & & & $\begin{array}{l}\text { Minimum } \\
\text { age }\end{array}$ & ${ }^{\mathrm{a}}(35.6 \pm 3.3)$ \\
\hline \multirow{2}{*}{$\mathrm{T}-8$} & TCAP-5C & \multirow{2}{*}{ Isochron burial dating } & 0.9916 & 9.32 & Estimate & \multirow{2}{*}{1360} \\
\hline & TCAP-5D & & 0.9862 & 15.38 & $\begin{array}{c}\text { with two } \\
\text { data points }\end{array}$ & \\
\hline $\mathrm{T}-9$ & AVA1-CN2 & $\begin{array}{l}\text { Surface exposure dating } \\
\qquad\left({ }^{36} \mathrm{Cl}\right)\end{array}$ & & & $\begin{array}{l}\text { Minimum } \\
\text { age }\end{array}$ & ${ }^{\mathrm{a}}(22.7 \pm 1.4)$ \\
\hline $\mathrm{T}-12$ & TCAP-2 & Simple burial dating & - & - & & $340 \pm 40$ \\
\hline \multirow[t]{6}{*}{$\mathrm{T}-12$} & TCAP-4A & Isochron burial dating & 0.8716 & 80.74 & & \multirow{6}{*}{$1560 \pm 80$} \\
\hline & TCAP-4B & & 1.0000 & 0.00 & & \\
\hline & TCAP-4C & & 0.9821 & 9.96 & & \\
\hline & TCAP-4D & & 0.9337 & 38.93 & & \\
\hline & TCAP-4E & & 0.5763 & 402.88 & & \\
\hline & TCAP-4F & & n.a. & & & \\
\hline \multirow[t]{7}{*}{$\mathrm{T}-13$} & TCAP-3A & Isochron burial dating & 1.0000 & 0 & & \multirow{7}{*}{$160 \pm 30$} \\
\hline & TCAP-3B & & 1.0000 & 0 & & \\
\hline & TCAP-3B2 & & 0.9773 & 23.94 & & \\
\hline & TCAP-3C & & 1.0000 & 0 & & \\
\hline & TCAP-3D & & 0.9880 & 12.49 & & \\
\hline & TCAP-3E & & 0.9759 & 25.51 & & \\
\hline & TCAP-3F & & 0.9842 & 16.48 & & \\
\hline
\end{tabular}

Exposure ages and production rates are calculated with the CRONUS-Earth exposure age calculator (http:// hess.ess.washington.edu /math/ (v. 2.2); Balco et al., 2008 and update from v. 2.1 to v. 2.2 published by Balco in October 2009) and constant Lal (1991)/Stone (2000) scaling model. A half-life of $1.39 \mathrm{Ma}$ for ${ }^{10} \mathrm{Be}$ (Korschinek et al., 2010; Chmeleff et al., 2010) and $720 \mathrm{ka}$ for ${ }^{26} \mathrm{Al}$ (Norris et al., 1983; Nishiizumi, 2004) are used for the age calculations. A mean life of $2.005 \mathrm{Ma}$ for ${ }^{10} \mathrm{Be}$ and of $1.02 \mathrm{Ma}$ for ${ }^{26} \mathrm{Al}$ are assumed (Granger and Muzikar, 2001).

${ }^{a}$ Minimum exposure ages from the surface samples were excluded for the reconstruction of the incision history. 
Table 4. Incision rates of the Kızlırmak based on dated terraces

\begin{tabular}{|l|c|c|c|}
\hline Terrace & Height $^{\mathrm{a}}(\mathrm{m})$ & Age $(\mathrm{ka})$ & Incision Rate $^{\mathrm{b}}(\mathrm{mm} / \mathrm{a})$ \\
\hline T6 & $100 \pm 2$ & $1890 \pm 100$ & $0.053 \pm 0.03$ \\
\hline T8 & $75 \pm 2$ & ${ }^{\mathrm{c}} 1360$ & ${ }^{\mathrm{d}} 0.055$ \\
\hline T12 & $20 \pm 2$ & $340 \pm 40$ & $0.059 \pm 0.01$ \\
\hline T13 & $13 \pm 2$ & $160 \pm 30$ & $0.081 \pm 0.02$ \\
\hline
\end{tabular}

${ }^{\mathrm{a}}$ Height above the modern river level

${ }^{\mathrm{b}}$ Incision rate according the modern level of the Kızılırmak

${ }^{\mathrm{c}}$ Estimated isochron age (see Table 3)

${ }^{d}$ Incision rate calculated based on the isochron age estimation 
Figure 1
Click here to download high resolution image

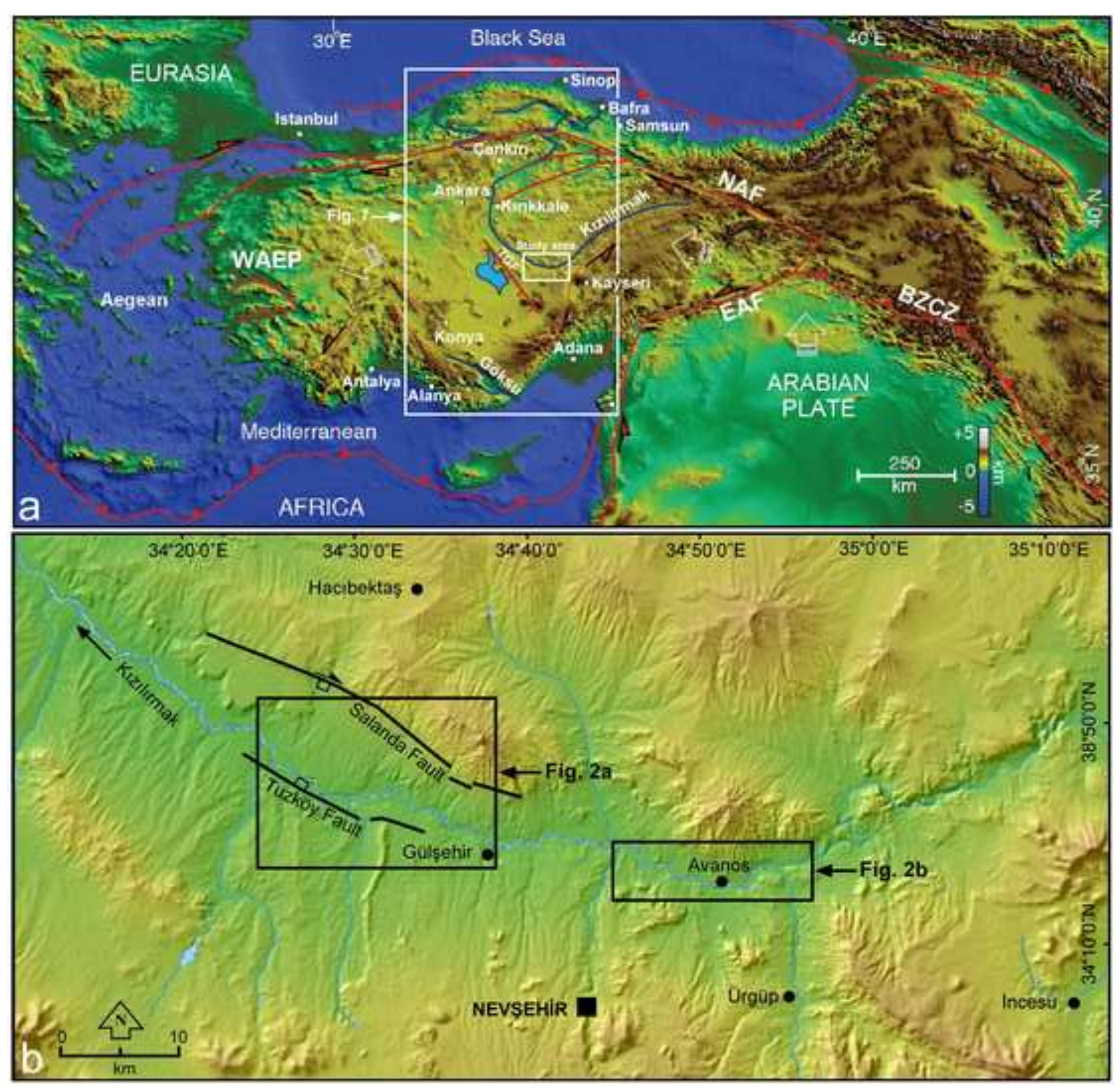




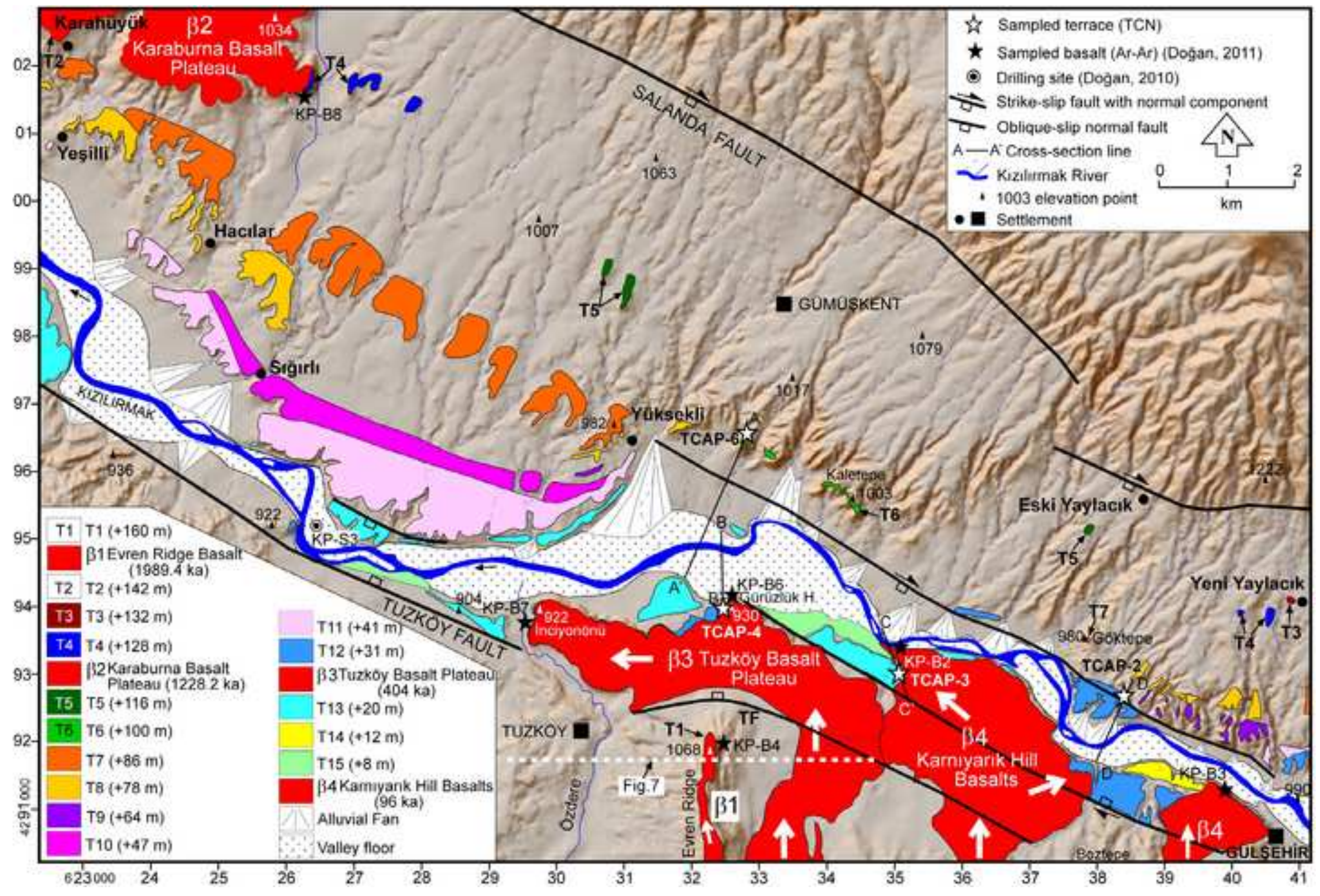




\section{Figure 2}

Click here to download high resolution image

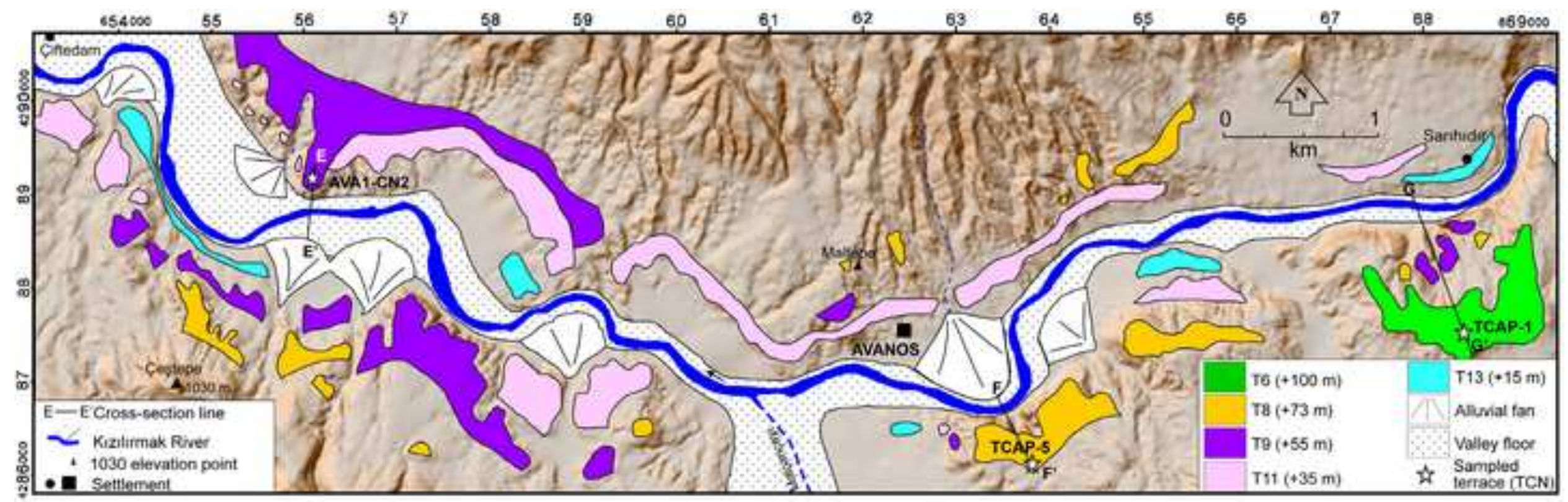




\section{Figure 3}

Click here to download high resolution image

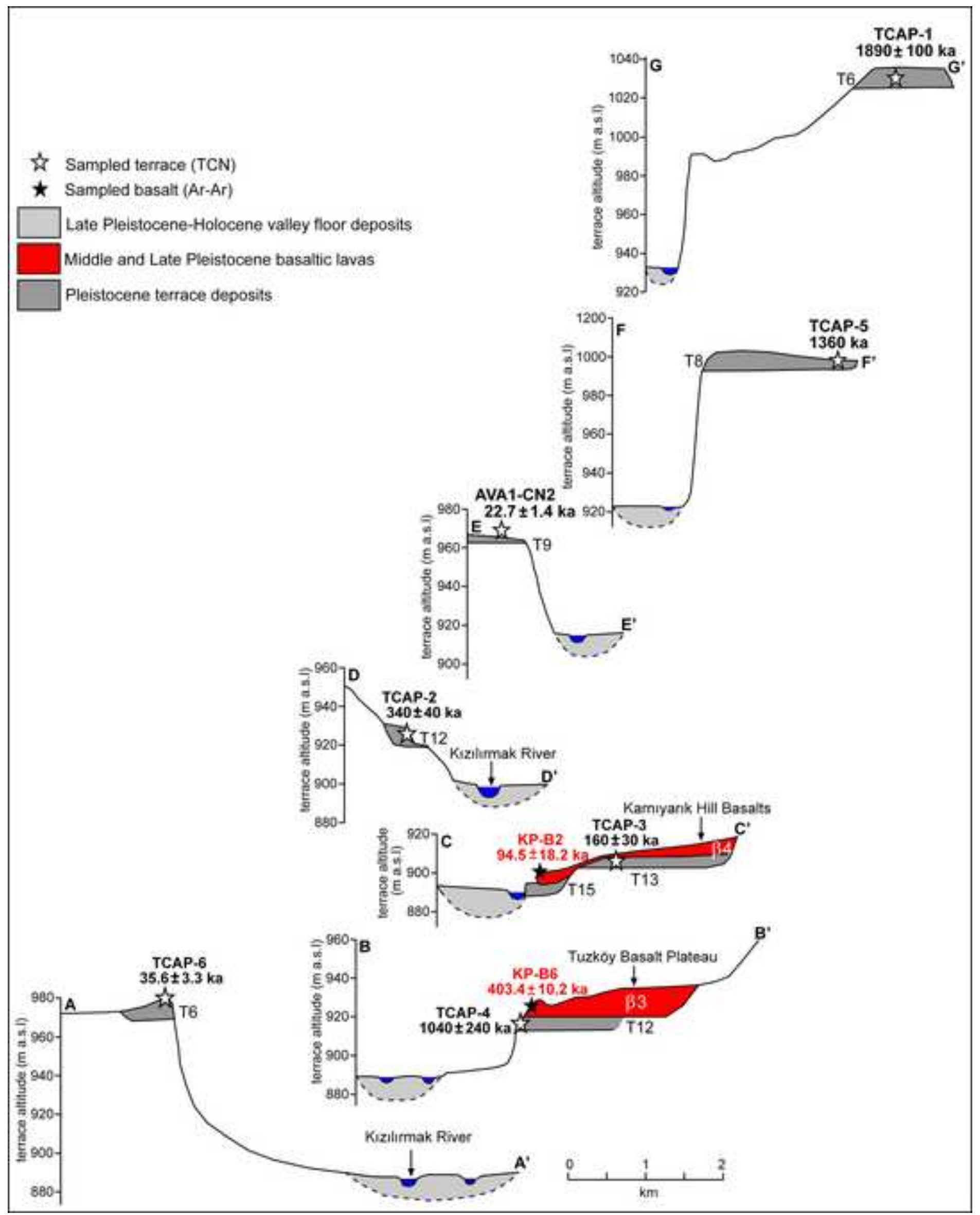






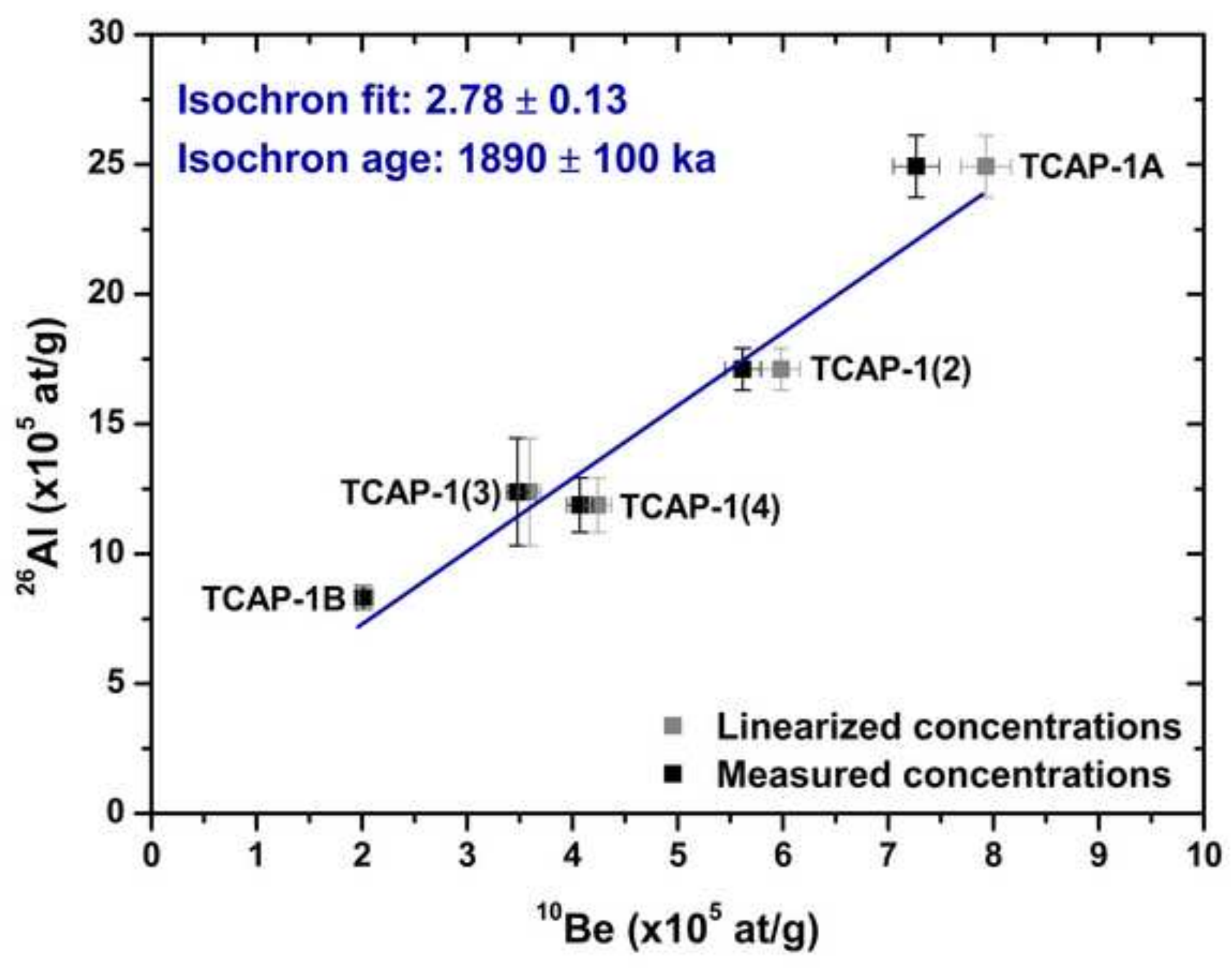



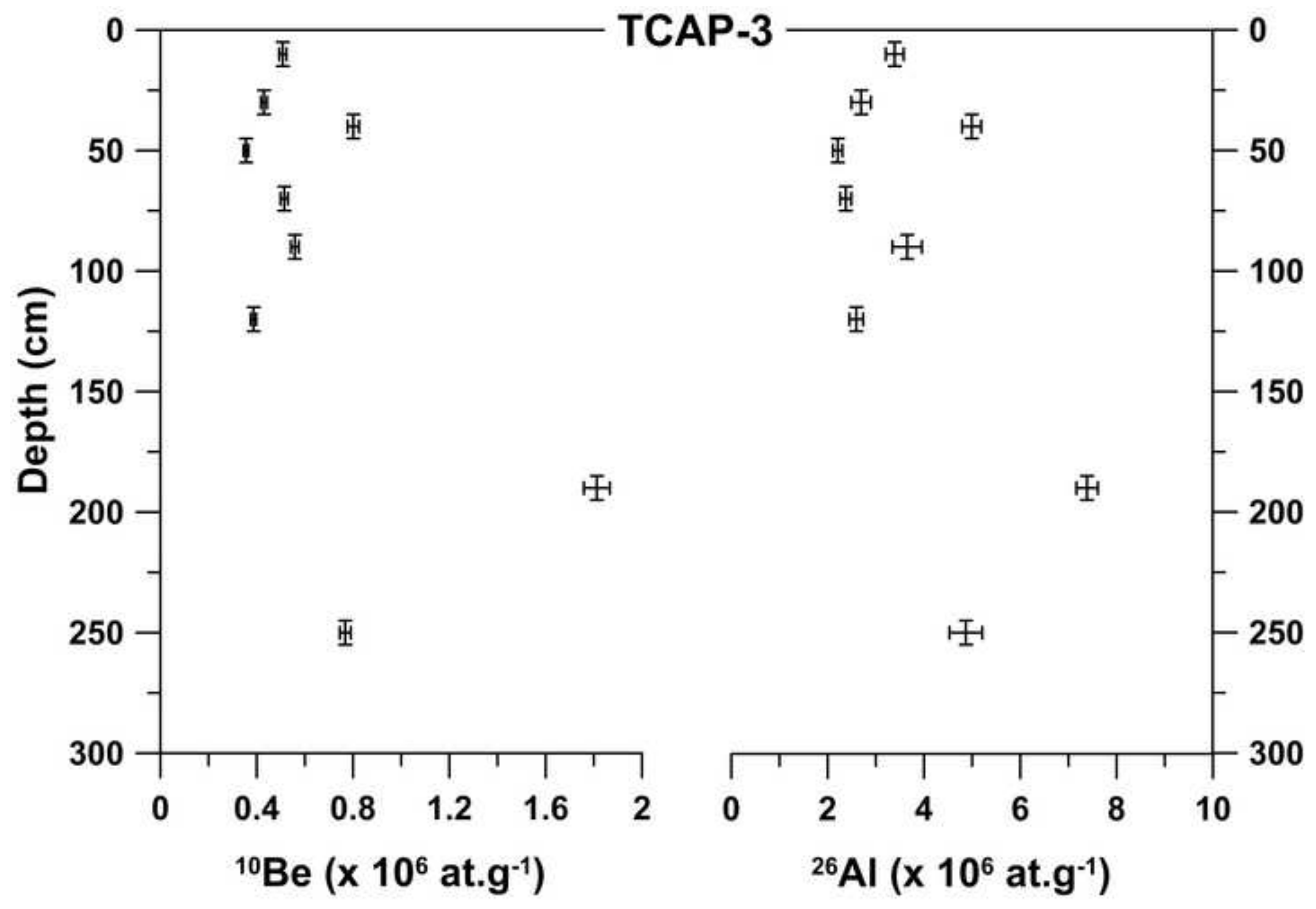


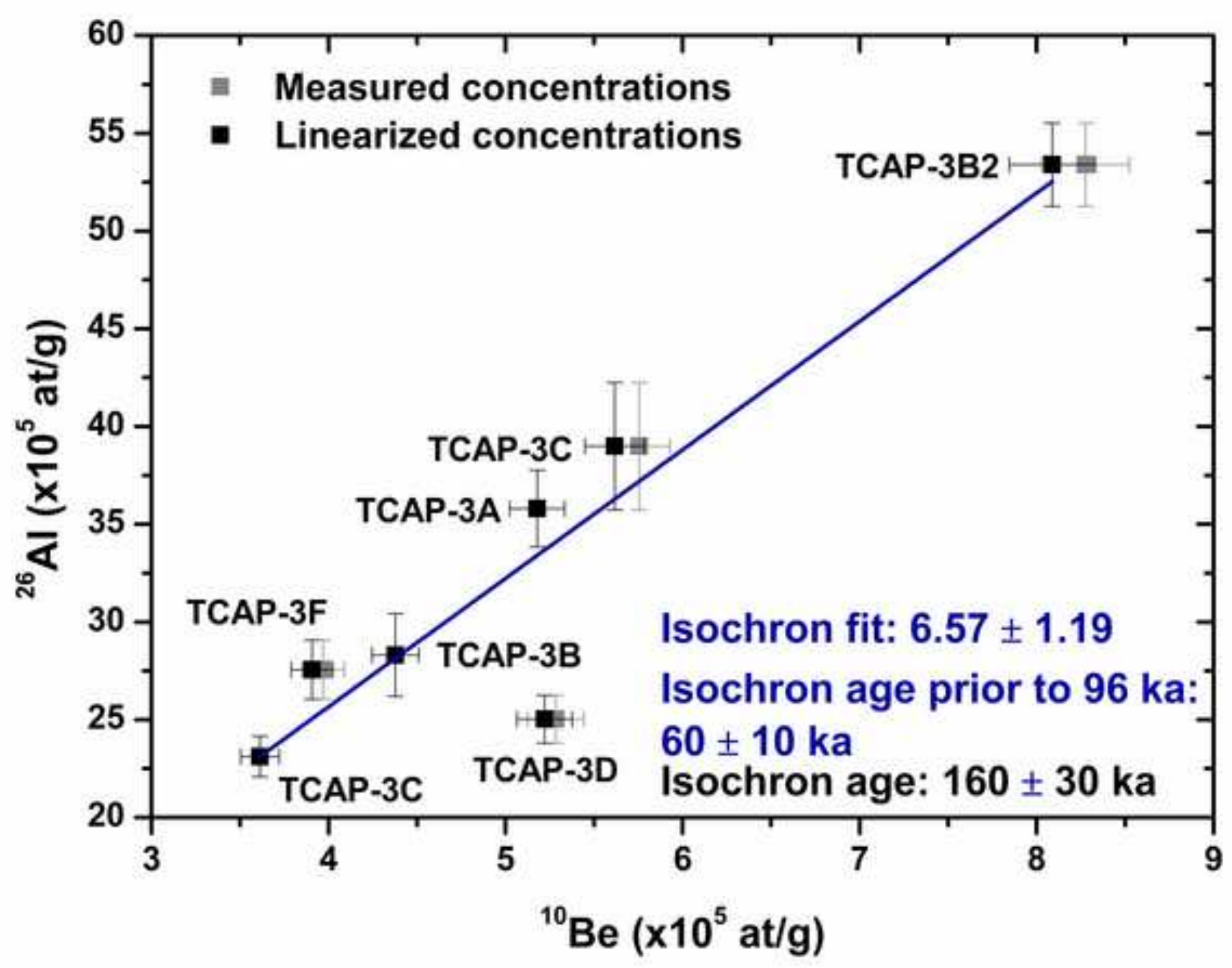




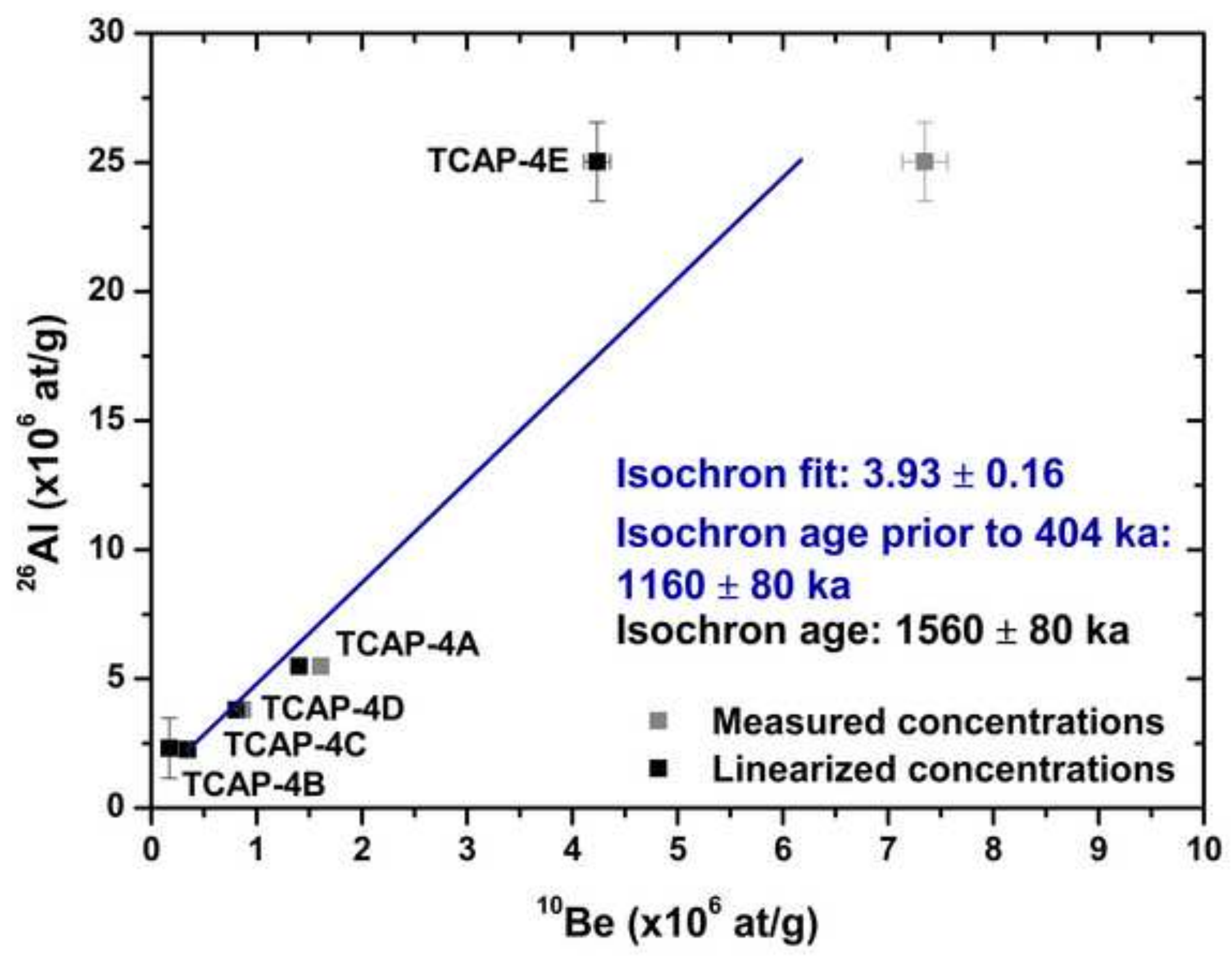




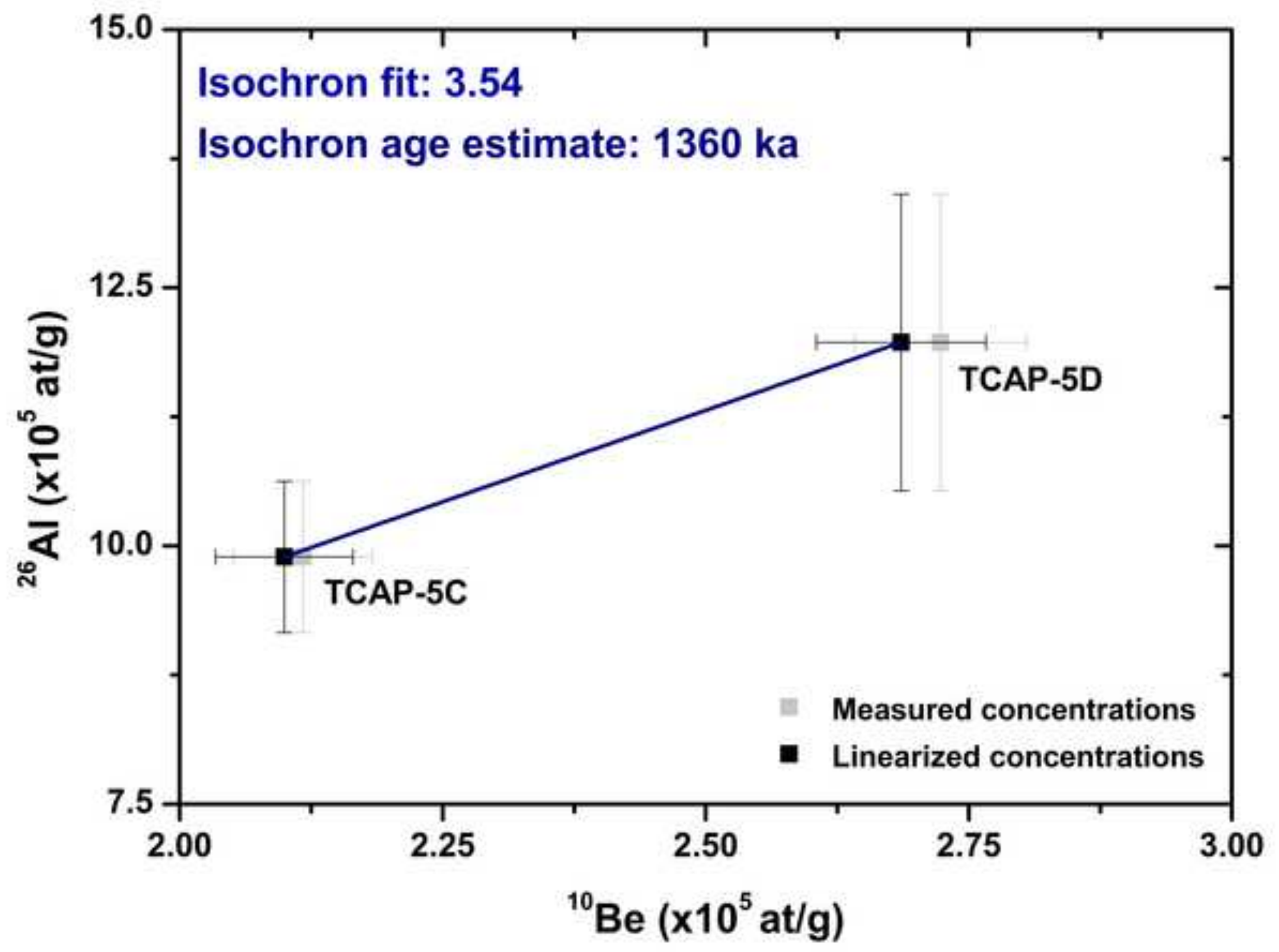




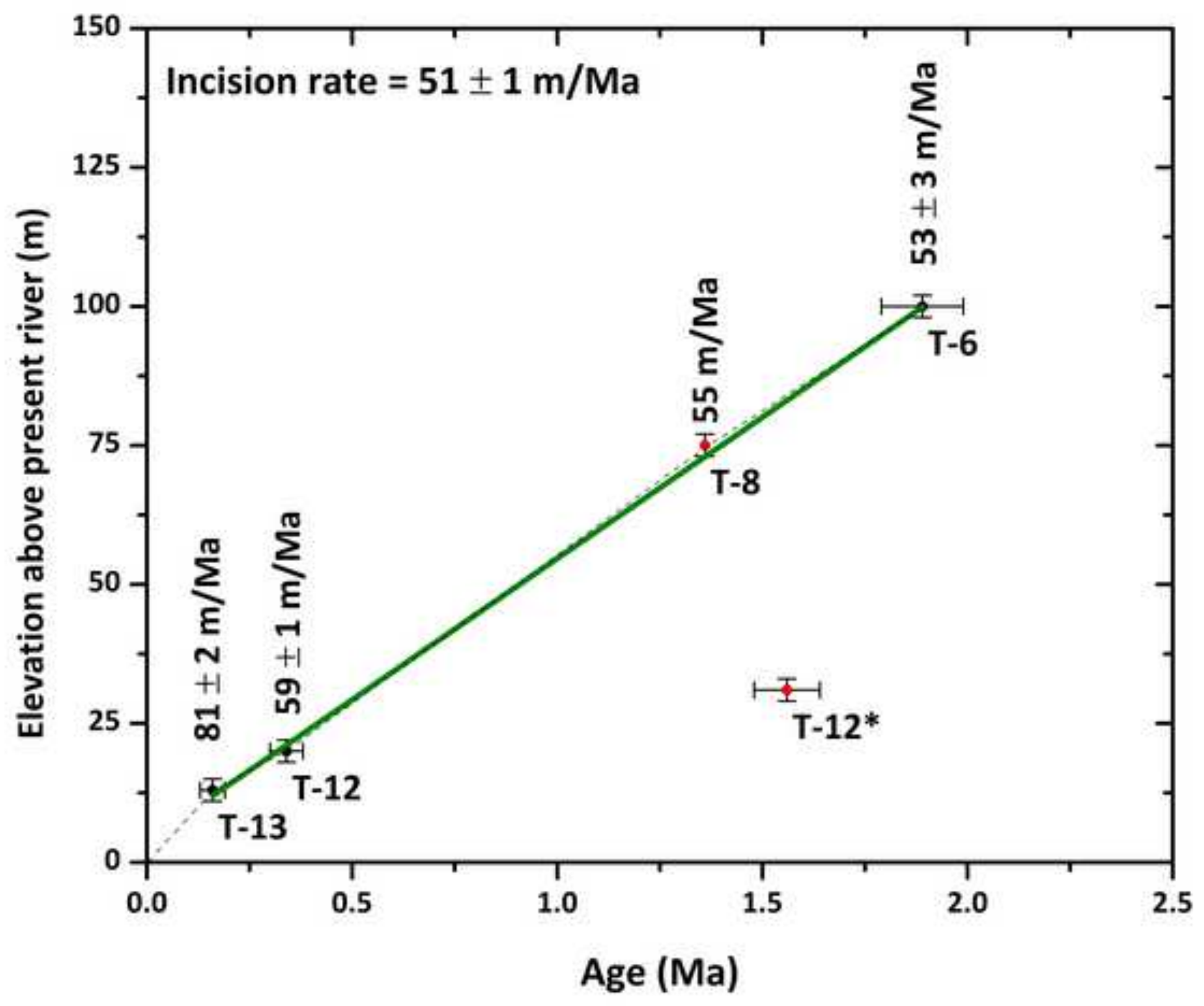


Click here to download high resolution image

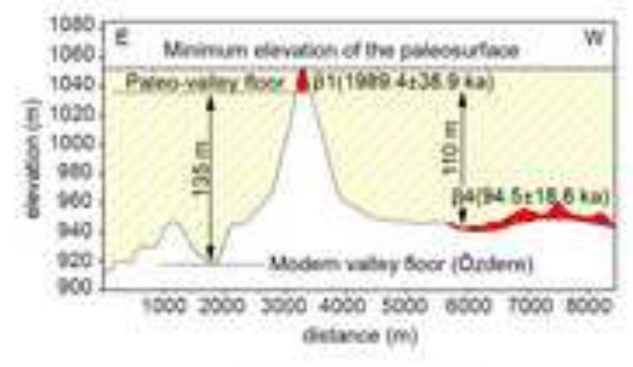

Figure 7. Ciner et al 
Figure
Click here to download high resolution image

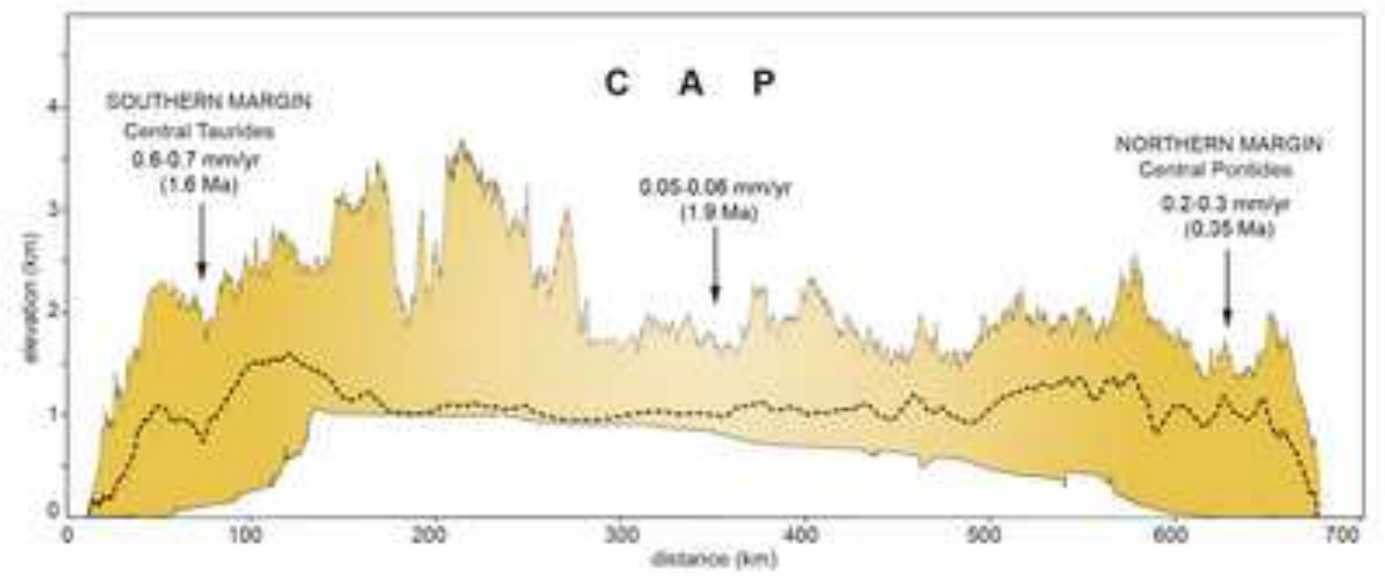

Figure 8 Cines et al. 

Appendix 1
Click here to download Supplementary Data: Appendix 1.docx

Appendix 1
Click here to download Supplementary Data: Appendix 1.docx

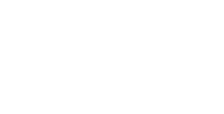

(1)

(1)

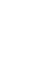

(1)

(1)

(1)

(1)

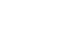
(1) . . . . . . . . . . . 